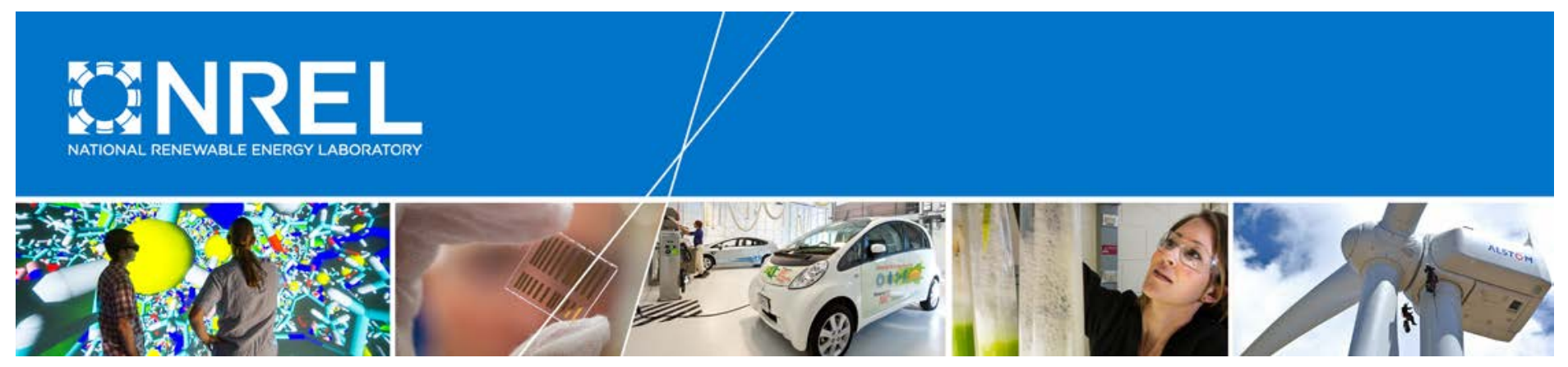

\title{
Systematic Review of Life Cycle Greenhouse Gas Emissions from Geothermal Electricity
}

Annika Eberle, Garvin Heath, Scott Nicholson, and Alberta Carpenter National Renewable Energy Laboratory

NREL is a national laboratory of the U.S. Department of Energy Office of Energy Efficiency \& Renewable Energy Operated by the Alliance for Sustainable Energy, LLC

This report is available at no cost from the National Renewable Energy Laboratory (NREL) at www.nrel.gov/publications.

Technical Report

NREL/TP-6A20-68474

September 2017

Contract No. DE-AC36-08G028308 


\section{Systematic Review of Life Cycle Greenhouse Gas Emissions from Geothermal Electricity}

\author{
Annika Eberle, Garvin Heath, \\ Scott Nicholson, and Alberta Carpenter \\ National Renewable Energy Laboratory
}

Prepared under Task No. GTP5.0341
NREL is a national laboratory of the U.S. Department of Energy Office of Energy Efficiency \& Renewable Energy Operated by the Alliance for Sustainable Energy, LLC

This report is available at no cost from the National Renewable Energy Laboratory (NREL) at www.nrel.gov/publications.

\section{Technical Report}

NREL/TP-6A20-68474

September 2017

Contract No. DE-AC36-08GO28308
15013 Denver West Parkway

Golden, CO 80401

303-275-3000 • www.nrel.gov 


\section{NOTICE}

This report was prepared as an account of work sponsored by an agency of the United States government. Neither the United States government nor any agency thereof, nor any of their employees, makes any warranty, express or implied, or assumes any legal liability or responsibility for the accuracy, completeness, or usefulness of any information, apparatus, product, or process disclosed, or represents that its use would not infringe privately owned rights. Reference herein to any specific commercial product, process, or service by trade name, trademark, manufacturer, or otherwise does not necessarily constitute or imply its endorsement, recommendation, or favoring by the United States government or any agency thereof. The views and opinions of authors expressed herein do not necessarily state or reflect those of the United States government or any agency thereof.

This report is available at no cost from the National Renewable Energy Laboratory (NREL) at www.nrel.gov/publications.

Available electronically at SciTech Connect http:/www.osti.gov/scitech

Available for a processing fee to U.S. Department of Energy and its contractors, in paper, from:

U.S. Department of Energy

Office of Scientific and Technical Information

P.O. Box 62

Oak Ridge, TN 37831-0062

OSTI http://www.osti.gov

Phone: 865.576.8401

Fax: 865.576.5728

Email: reports@osti.gov

Available for sale to the public, in paper, from:

U.S. Department of Commerce

National Technical Information Service

5301 Shawnee Road

Alexandria, VA 22312

NTIS http://www.ntis.gov

Phone: 800.553 .6847 or 703.605 .6000

Fax: 703.605.6900

Email: orders@ntis.gov 


\section{Acknowledgments}

This work was supported by the U.S. Department of Energy (DOE) under Contract No.

DEAC36-08GO28308 with the National Renewable Energy Laboratory (NREL). Funding for the work was provided by the DOE Office of Energy Efficiency and Renewable Energy, Geothermal Technologies Office. The authors would like to thank Chad Augustine (NREL) and Corrie Clark (Congressional Research Service, formerly of Argonne National Laboratory) for reviewing previous versions of this report. Opinions represented in this report are the authors' own and do not reflect the view of the DOE or the U.S. government. 


\section{Executive Summary}

The primary goal of this work was to assess the magnitude and variability of published life cycle greenhouse gas (GHG) emission estimates for three types of geothermal electricity generation technologies: enhanced geothermal systems (EGS) binary, hydrothermal (HT) flash, and HT binary. These technologies were chosen to align the results of this report with technologies modeled in National Renewable Energy Laboratory's (NREL's) Regional Energy Deployment Systems (ReEDs) model. Although we did gather and screen life cycle assessment (LCA) literature on hybrid systems, dry steam, and two geothermal heating technologies, we did not analyze published GHG emission estimates for these technologies.

In our systematic literature review of the LCA literature, we screened studies in two stages based on a variety of criteria adapted from NREL's Life Cycle Assessment (LCA) Harmonization study (Heath and Mann 2012). Of the more than 180 geothermal studies identified, only 29 successfully passed both screening stages and only 26 of these included estimates of life cycle GHG emissions. We found that the median estimate of life cycle GHG emissions (in grams of carbon dioxide equivalent per kilowatt-hour generated $\left[\mathrm{g} \mathrm{CO}_{2} \mathrm{eq} / \mathrm{kWh}\right]$ ) reported by these studies are 32.0, 47.0, and 11.3 for EGS binary, HT flash, and HT binary, respectively (Figure ES-1).
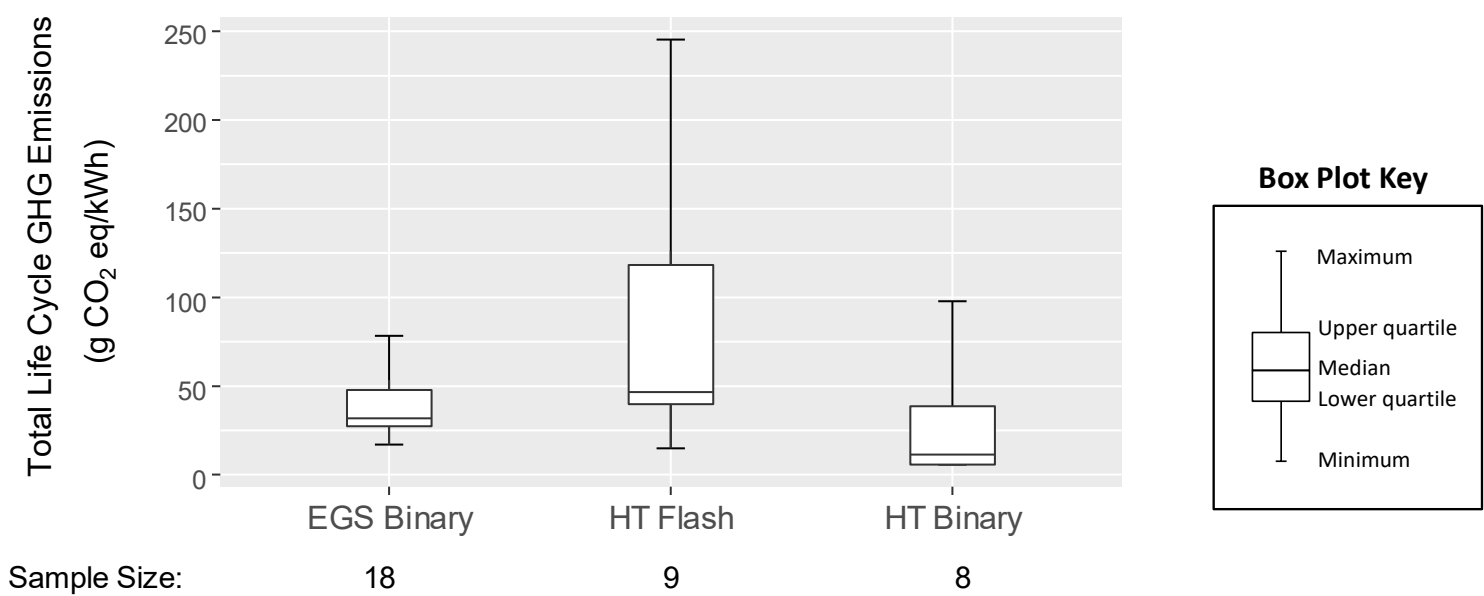

\section{Figure ES-1. Life cycle greenhouse gas emissions (GHG) for three types of geothermal electricity: enhanced geothermal systems (EGS) binary, hydrothermal (HT) flash and HT binary.}

We also found that the total life cycle GHG emissions are dominated by different stages of the life cycle for different technologies. For example, the GHG emissions from HT flash plants are dominated by the operations phase owing to the flash cycle being open loop whereby carbon dioxide entrained in the geothermal fluids is released to the atmosphere. This is in contrast to binary plants (using either EGS or HT resources), whose GHG emissions predominantly originate in the construction phase, owing to its closed-loop process design. Finally, by comparing this review's literature-derived range of HT flash GHG emissions to data from currently operating geothermal plants, we found that emissions from operational plants exhibit more variability and the median of emissions from operational plants is twice the median of operational emissions reported by LCAs. Further investigation is warranted to better understand the cause of differences between published LCAs and estimates from operational plants and to develop LCA analytical approaches that can yield estimates closer to actual emissions. 


\section{Table of Contents}

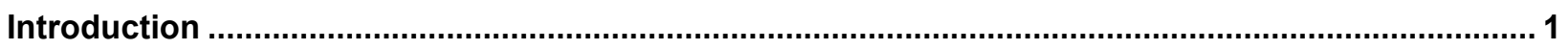

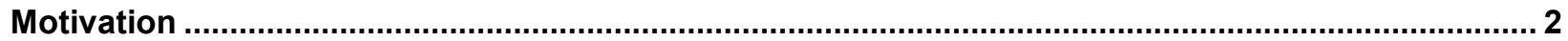

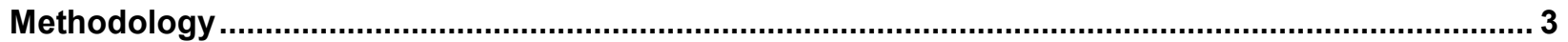

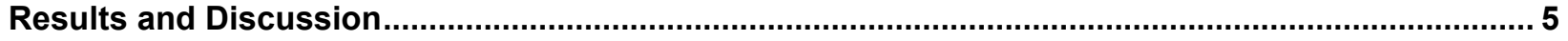

Overview of LCA Studies on GHG Emissions from Three Types of Geothermal Electricity.............. 7

Limitations of this Work and Opportunities for Harmonization ...................................................... 7

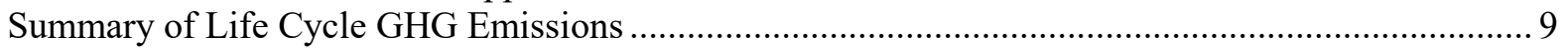

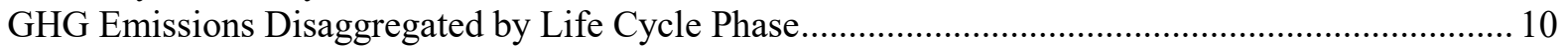

Importance of Operational Emissions ....................................................................................... 11

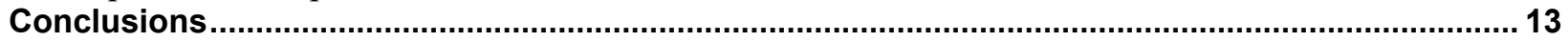

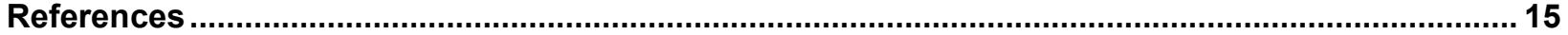

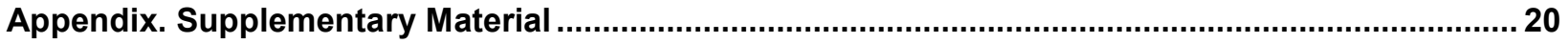




\section{List of Figures}

Figure ES-1. Life cycle greenhouse gas emissions (GHG) for three types of geothermal electricity: enhanced geothermal systems (EGS) binary, hydrothermal (HT) flash and HT binary. iv

Figure 1. Side-by-side comparison of life cycle greenhouse gas (GHG) emissions from three geothermal electricity generation technologies: enhanced geothermal systems (EGS) binary, hydrothermal (HT) flash and HT binary ....

Figure 2. Greenhouse gas (GHG) emissions disaggregated by phase of the life cycle (i.e., total, construction, operation, and end of life) for three geothermal electricity generation technologies: enhanced geothermal systems (EGS) binary, hydrothermal (HT) flash, and HT binary.

Figure 3. Comparison of carbon dioxide $\left(\mathrm{CO}_{2}\right)$ emissions reported by operational geothermal plants (compiled from Bertani and Thain 2002, Holm et al. 2012, Sullivan and Wang 2013, and Bravi and Basosi 2014) versus GHG emissions computed from life cycle assessments (LCAs) of electricity generated by hydrothermal (HT) flash plants (same values as reported in Figures 1 and 2 above). . 12 


\section{List of Tables}

Table 1. Criteria Used to Perform the Second Screen, which Evaluated the Study's Quality, Transparency,

Completeness, and Relevance..... 3

Table 2. Studies that Passed both Screens and Produced an Estimate for the Life Cycle Environmental Impact of Geothermal Technologies...... 6

Table 3. Details about Studies that Passed the Screening Criteria and Produced an Estimate of Life Cycle Greenhouse Gas (GHG) Emissions for Electricity Produced by Three Types of Geothermal Energy 8

Table A-1. Statistics for Estimates of Total Life Cycle GHG Emissions from Three Types of Geothermal Electricity: EGS Binary, HT Binary, and HT Flash ....

Table A-2. Statistics for Estimates of GHG Emissions from the Construction Phase of Three Types of Geothermal Electricity: EGS Binary, HT Binary, and HT Flash.

Table A-3. Statistics for Estimates of GHG Emissions from the Operation Phase of Three Types of Geothermal Electricity: EGS Binary, HT Binary, and HT Flash.

Table A-4. Statistics for Estimates of GHG Emissions from the End of Life Phase of Three Types of Geothermal Electricity: EGS Binary, HT Binary, and HT Flash

Table A-5. Statistics for Estimates Reported in Figure 3, including the Operational CO2 Emissions Reported by Geothermal Plants that are Currently Operating and the GHG Emissions Computed via LCA of HT Flash Technology (Same as Column 3 in Table A3) .21

Table A-6. Life Cycle GHG Estimates from the 29 Studies that Passed both Rounds of Screening ......... 21

Table A-7. Sources Screened, with Results for Each Screening Criterion ................................................ 23

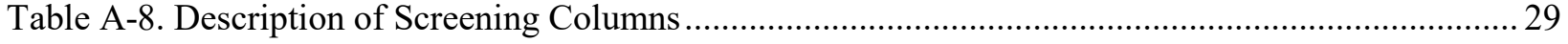




\section{Introduction}

Thermal energy stored in rock, steam, or liquid water can be extracted and used in thermal power plants to produce electricity, heat, or combined heat and power. Although some direct uses of geothermal energy, such as bathing in hot springs, have been used for thousands of years (Cataldi 1999), geothermal power generation technologies were not developed until the early 1900s (Burgassi 1999).

The first geothermal power plant used dry steam that came directly out of a geofield found in Lardarello, Italy. Geothermal power generation methods now include hydrothermal systems and enhanced geothermal systems (EGSs). Hydrothermal (HT) methods bring in-situ geofluids from naturally-occurring geothermal reservoirs to the surface to power a turbo generator either (1) indirectly in a binary cycle plant, which passes the geofluid through a heat exchanger using a secondary working fluid to turn the generator or (2) directly in a flash plant, where the geofluid is vaporized to generate steam which turns the generator. An EGS uses the same power generation method via a turbo generator with binary or flash technology. However, an EGS uses hydraulic stimulation to create fluid connectivity in geothermal systems that do not have adequate water or permeability.

Geothermal energy presents several advantages over other renewable energy technologies, including that it can provide year-round baseload power. However, in 2015, geothermal energy only comprised approximately $0.2 \%$ of the world's primary energy supply (Lund and Boyd 2016, EIA 2016), including 73 terawatt-hours of geothermal electricity (Bertani 2016). Despite the current limited use of geothermal resources, estimates of the global technical potential indicate that geothermal resources could comprise anywhere from 127 exajoules/year to 1,420 exajoules/year, or $25 \%-280 \%$ of the world's 2008 energy consumption (IPCC 2011). The large range of these estimates is due to variations in technological advances, including the ability to commercialize EGSs, which would allow access to potential resources at greater depths and in more geographic regions. 


\section{Motivation}

With its abundance and reliability, geothermal energy presents opportunities for reducing the world's dependence on fossil fuels for power and heat generation. In addition, because geothermal power plants have been shown, in almost all cases, to have lower greenhouse gas (GHG) emissions than fossil fuel-fired power plants (Sullivan et al. 2010), they could also help mitigate climate change impacts. However, estimates for the environmental impacts of geothermal power plants vary considerably. In some cases, the estimates of GHGs emitted per kilowatt-hour of geothermal electricity are five to ten times larger than the median values reported for wind and solar technologies (IPCC 2011).

Although authors of many prior studies have performed life cycle assessments (LCAs) to evaluate the environmental impacts of geothermal energy, only two have compared the results from multiple studies (Sullivan et al. 2010; IPCC 2011). Sullivan et al. (2010) developed an LCA for geothermal power plants and compared their results to five other studies, but they did not comprehensively review all available LCAs. Researchers at the National Renewable Energy Laboratory (NREL) systematically reviewed 46 geothermal LCAs in 2011 in support of the Intergovernmental Panel on Climate Change (IPCC) Special Report on Renewable Energy Sources and Climate Change Mitigation (SRREN) (IPCC 2011). For the 2011 IPCC SRREN, only nine published studies passed the screening process of NREL's LCA Harmonization Study (Heath and Mann 2012) and, of those, only six provided estimates of life cycle GHG emissions.

Several new LCAs of geothermal technologies have been published since IPCC (2011) and Sullivan et al. (2010). The goal of this work is to build on prior work by incorporating the latest studies in order to decrease the uncertainty around these estimates and increase their value for research and policymaking. Thus, we performed a thorough review of the LCA literature regarding environmental impacts associated with geothermal technologies and then screened the resulting studies using the similar methods to those employed in NREL's LCA Harmonization Study (Heath and Mann 2012). 


\section{Methodology}

The methods for this current comprehensive literature review were adapted from Heath and Mann (2012) and include a series of two screens. The first screen evaluates whether the study:

- Is written in English;

- Was published after 1980;

- Was published as:

○ An archival journal article or trade journal article greater than three published pages in length,

○ A conference proceeding greater than five double-spaced pages in length, or

○ A book or book chapter, thesis, dissertation, or report;

- Covers geothermal energy; and

- Reports quantitative results from an LCA or reviews results from multiple LCAs.

The second screen, as outlined in Table 1, evaluates the quality, transparency, completeness, and relevance of the studies that pass the first screen.

Table 1. Criteria Used to Perform the Second Screen, which Evaluated the Study's Quality, Transparency, Completeness, and Relevance

\begin{tabular}{|c|c|}
\hline $\begin{array}{l}\text { Category for } \\
\text { Second Screen }\end{array}$ & Criteria \\
\hline \multirow[t]{3}{*}{ Quality } & $\begin{array}{l}\text { Uses a currently accepted LCA method (e.g., follows guideline } 14040 \text { from the } \\
\text { International Organization for Standardization (ISO 2006)) }\end{array}$ \\
\hline & $\begin{array}{l}\text { Employs a relevant impact assessment method (e.g., selected impact categories, } \\
\text { category indicators, and characterization methods) }\end{array}$ \\
\hline & Evaluates at least two life cycle stages \\
\hline \multirow[t]{7}{*}{$\begin{array}{l}\text { Transparency and } \\
\text { Completeness }\end{array}$} & $\begin{array}{l}\text { Reports their method transparently with regard to key parameters, assumptions } \\
\text { and methods (e.g., defines a system boundary) }\end{array}$ \\
\hline & $\begin{array}{l}\text { Provides a numerical description of the system characteristics (e.g., plant size or } \\
\text { well depth) }\end{array}$ \\
\hline & Reports the environmental impact estimates quantitatively \\
\hline & If appropriate, reports the name of LCA software or database used for the analysis \\
\hline & Provides citations for data sources \\
\hline & Reports a unique estimate of the result (i.e., the result is not cited from prior work) \\
\hline & Provides enough information to scale results by plant generation \\
\hline Relevance & $\begin{array}{l}\text { Evaluates a modern or near-future system (e.g., supercritical carbon dioxide }\left[\mathrm{CO}_{2}\right] \\
\text { as a working fluid). Geo-pressured geothermal systems were excluded. }\end{array}$ \\
\hline
\end{tabular}


After screening the literature, we compiled data from studies that passed all criteria in both screens and also reported estimates of life cycle GHG emissions from geothermal electricity generated by three technology types: EGS binary, HT flash, and HT binary. We did not compile water use estimates from any study because detailed analysis of water use was outside the scope of this work, nor did we compile GHG emission estimates for direct use heating, hybrid, and dry steam systems because those technologies are not modeled within NREL's Regional Energy Deployment System (ReEDS) model.

For the three types of geothermal electricity investigated, we computed the central tendency and variability in published estimates of GHG emissions for the total life cycle and by life cycle phase (i.e., construction, operation, and end-of-life). If the sample size for the estimates was greater than four, we computed the central tendency using the median and the variability using the interquartile range (i.e., the spread of the middle $50 \%$ of the estimates; lower and upper quartiles correspond to the $25^{\text {th }}$ and $75^{\text {th }}$ percentiles respectively) and the total range (i.e., minimum and maximum values). We used these statistics to generate box plots of the total and phase-disaggregated life cycle GHG emissions for the three technology types. These estimates are compatible with ReEDS modeling of life cycle GHG emissions for future power sector deployment scenarios such as for Vision studies performed by the U.S. Department of Energy (DOE) (Wind Vision, Hydropower Vision, etc.) (DOE 2015; DOE 2016).

There are several differences between this report and NREL's prior harmonization studies of other energy technologies. First, unlike prior NREL harmonization studies, this work only performs a systematic review of the literature and compiles the resulting estimates for life cycle GHG emissions. We do not harmonize the estimates to reflect consistent performance characteristics, life cycle stages, or global warming potentials because such an analysis was outside the scope of this work. Second, to build broad knowledge of the life cycle impacts of geothermal energy, we do not limit our literature survey to only GHG emissions. Instead, we also include studies that report water use (Table 2). 


\section{Results and Discussion}

To build broad knowledge of the life cycle impacts of geothermal energy and to assist future researchers in identifying literature on these topics, we initially performed a literature search, which in addition to identifying LCAs containing estimates of life cycle GHG emissions also identified LCAs containing estimates of life cycle water use. For the same reasons, we also initially searched more broadly on a technology basis than the three geothermal technologies that this report focuses its analysis on. The initial technologies included:

- Electricity generated by

1. EGS binary: EGSs used in the operation of binary cycle power plants,

2. HT binary: HT resources used in binary cycle plants,

3. HT flash: high-temperature HT resources that are vaporized and used in flash steam plants,

4. Dry steam: steam that directly drives a turbine, and

5. Hybrid systems: the combination or two or more electricity generation technologies (e.g., geothermal and solar); and

- Heat generated by

6. Combined heat and power: simultaneous production of heat and electricity from geothermal energy, and

7. Geothermal heat pumps: pumps that transfer heat to or from the ground.

We then focused our analysis on GHG emissions from geothermal electricity and analyzed the three geothermal electricity generation technologies for which multiple LCAs had been performed and which align with the technologies modeled in NREL's ReEDS model: EGS binary, HT binary, and HT flash.

Of more than 180 geothermal environmental impact studies identified through our systematic review procedures of this literature, only 82 passed the first screen and 29 of those passed the second screen (Table 2). The 29 studies that passed both screens produced more than 40 estimates for two types of environmental impacts - GHG emissions and water use. Three of the studies we identified were included in the comparison performed by Sullivan et al. (2010) (italicized and highlighted in grey in Table 2). Five of the studies were also reported by NREL in the IPCC SRREN (2011) (listed in bold in Table 2). 
Table 2. Studies that Passed both Screens and Produced an Estimate for the Life Cycle Environmental Impact of Geothermal Energy ${ }^{a}$

\begin{tabular}{|c|c|c|c|}
\hline Technology Type & Author and Year & Publication Type & Type of Environmental Impact \\
\hline \multirow[t]{11}{*}{ EGS binary } & Rogge and Kaltschmitt 2003 & Journal article & GHG emissions \\
\hline & Bauer et al. 2008 & Conference paper & GHG emissions \\
\hline & Frick et al. 2010 & Journal article & GHG emissions \\
\hline & Clark et al. 2011 & Report & Water use \\
\hline & Clark et al. 2013 & Report & Water use \\
\hline & Heberle et a. 2016 & Journal article & GHG emissions \\
\hline & Lacirignola and Blanc 2013 & Journal article & GHG emissions \\
\hline & Meldrum et al. 2013 & Journal article & Water use \\
\hline & Sullivan et al. 2013 & Journal article & GHG emissions \\
\hline & Sullivan et al. 2014 & Report & GHG emissions \\
\hline & Treyer et al. 2014 & Journal article & GHG emissions \\
\hline \multirow[t]{7}{*}{ HT binary } & Rule et al. 2009 & Journal article & GHG emissions \\
\hline & Clark et al. 2011 & Report & Water use \\
\hline & Clark et al. 2013 & Report & Water use \\
\hline & Meldrum et al. 2013 & Journal article & Water use \\
\hline & Sullivan et al. 2013 & Journal article & GHG emissions \\
\hline & Sullivan et al. 2014 & Report & GHG emissions \\
\hline & Martin-Gamboa et al. 2015 & Journal article & GHG emissions \\
\hline \multirow[t]{10}{*}{ HT flash } & Hondo 2005 & Journal article & GHG emissions \\
\hline & Karlsdottir et al. 2010a & Conference paper & GHG emissions \\
\hline & Clark et al. 2011 & Report & Water use \\
\hline & Skone et al. 2012 & Report & GHG emissions \\
\hline & Clark et al. 2013 & Report & Water use \\
\hline & Marchand et al. 2015 & Conference paper & GHG emissions \\
\hline & Martínez-Corona et al. 2017 & Journal article & GHG emissions \\
\hline & Meldrum et al. 2013 & Journal article & Water use \\
\hline & Sullivan et al. 2013 & Journal article & GHG emissions \\
\hline & Sullivan et al. 2014 & Report & GHG emissions \\
\hline \multirow{3}{*}{$\begin{array}{l}\text { Combined heat } \\
\text { and power }\end{array}$} & Karlsdottir et al. $2010 \mathrm{~b}$ & Conference paper & GHG emissions \\
\hline & Ruzzenenti et al. 2014 & Journal article & GHG emissions \\
\hline & Martin-Gamboa et al. 2015 & Journal article & GHG emissions \\
\hline \multirow[t]{8}{*}{ Heat pump } & Gilli et al. 1999 & Report & GHG emissions \\
\hline & Genchi et al. 2002 & Journal article & GHG emissions \\
\hline & Saner et al. 2010 & Journal article & GHG emissions \\
\hline & Ghafghazi et al. 2011 & Journal article & GHG emissions \\
\hline & Ristimäki et al. 2013 & Journal article & GHG emissions \\
\hline & Russo et al. 2014 & Journal article & GHG emissions \\
\hline & Kim et al. 2015 & Journal article & GHG emissions \\
\hline & Mattinen et al. 2015 & Journal article & GHG emissions \\
\hline Hybrid & Ristimäki et al. 2013 & Journal article & GHG emissions \\
\hline Dry steam & Buonocore et al. 2015 & Journal article & GHG emissions \\
\hline
\end{tabular}

a) Grey coloring and italicized text highlights studies included in the comparison of life cycle greenhouse gas (GHG) emissions from geothermal electricity performed by Sullivan et al. (2010). Bold text corresponds to studies reported in the IPCC SRREN (2011). EGS = enhanced geothermal system, and HT = hydrothermal. 


\section{Overview of Estimates of Life Cycle GHG Emissions from Three Types of Geothermal Electricity}

The primary goal of this work was to evaluate the life cycle GHG emissions associated with the two main types of geothermal energy currently used to generate electricity - hydrothermal (HT) and enhanced geothermal systems (EGS) - because these are the two types of geothermal electricity modeled in NREL's ReEDS model. As a result, we only extracted raw data from studies passing our screens for three technologies: HT binary, HT flash, and EGS binary. It is important to note that while EGS is considered a viable technology (DOE 2004), it is not yet commercialized and none of the LCA studies that passed our screens examined the total environmental impacts associated with EGS flash.

As shown in Table 3, the location, impact assessment methods, life cycle phases, lifetime, plant size, depth, and temperature evaluated for the three electricity generation technologies vary by study. The locations range from Germany to the United States and Japan, and the primary impact assessment method is based on the global warming potentials reported by the IPCC in 2007. The average operating lifetime is generally between 20 and 30 years, but one study (Rule et al. 2009) assumes 100 years. In addition, while all of these studies include the life cycle phases of construction and operation, some also include the impacts associated with exploratory drilling (exploration) and end-of-life (EOL). Although most studies report results for plant sizes of around 10 megawatts (MW), the sizes range from 900 kilowatts $(\mathrm{kW})$ to $300 \mathrm{MW}$.

\section{Limitations of this Work and Opportunities for Harmonization}

As evidenced by the variations in the parameters employed by the LCA studies analyzed here, there are many opportunities for harmonizing the results to use similar global warming potentials, operating lifetimes, plant sizes, and system boundaries, as was done for most generation technologies evaluated in NREL's LCA Harmonization Study (follow hyperlink for complete list). However, the process of harmonization is outside the scope of this work.

It is also important to note that multiple environmental impact estimates are often reported by a single reference. For example, as indicated in Table 3, there are eighteen life cycle GHG estimates for EGS binary but they only come from seven different studies and ten estimates come from a single study by Lacirignola and Blanc (2013). Although these estimates explore the impact of depth and temperature, having multiple results from a single study may skew the overall results because of similarities in methods. 
Table 3. Summary of Studies that Passed the Screening Criteria and Produced an Estimate of Life Cycle GHG Emissions for Three Types of Geothermal Electricity: Enhanced Geothermal Systems (EGS) Binary, Hydrothermal (HT) Binary and HT Flash

\begin{tabular}{|c|c|c|c|c|c|c|c|c|c|c|c|c|}
\hline \multirow{2}{*}{ Author(s) } & \multirow[t]{2}{*}{ Year } & \multirow{2}{*}{$\begin{array}{l}\text { Estimate } \\
\text { Count }\end{array}$} & \multirow[t]{2}{*}{ Location } & \multirow{2}{*}{$\begin{array}{c}\text { Impact Assessment } \\
\text { Method }^{\mathrm{b}}\end{array}$} & \multicolumn{4}{|c|}{$\begin{array}{c}\text { Inclusion of Life Cycle } \\
\text { Phases }^{c}\end{array}$} & \multirow{2}{*}{\begin{tabular}{|l} 
System \\
Lifetime \\
(years)
\end{tabular}} & \multirow{2}{*}{$\begin{array}{l}\text { Size } \\
(\mathrm{MW})\end{array}$} & \multirow{2}{*}{$\begin{array}{l}\text { Depth } \\
\text { (km) }\end{array}$} & \multirow{2}{*}{$\begin{array}{l}\text { Temp.d } \\
\left({ }^{\circ} \mathbf{C}\right)\end{array}$} \\
\hline & & & & & Explor. & Constr. & O\&M & $E O L$ & & & & \\
\hline \multicolumn{13}{|c|}{ EGS Binary Technology ${ }^{a}$} \\
\hline Rogge and Kaltschmitt & 2003 & 2 & Germany & IPCC 1995 & & $\checkmark$ & $\checkmark$ & $\checkmark$ & - & 0.9 & $3-4.5$ & 150 \\
\hline Bauer et al. & 2008 & 1 & Switzerland & IPCC 2007 & & $\checkmark$ & $\checkmark$ & $\checkmark$ & 30 & 36 & 5.5 & 150 \\
\hline Frick et al. & 2010 & 2 & Europe & Frick et al. 2010, Table 1 & $\checkmark$ & $\checkmark$ & $\checkmark$ & $\checkmark$ & 30 & 1.75 & $3.8-4.7$ & $125-150$ \\
\hline Lacirignola and Blanc & 2013 & 10 & Germany & IMPACT 2002+ & & $\checkmark$ & $\checkmark$ & $\checkmark$ & 25 & $1-6$ & $2.5-4$ & $145-165$ \\
\hline Sullivan et al. & 2013 & 1 & United States & IPCC 2007 & $\checkmark$ & $\checkmark$ & $\checkmark$ & & 30 & 20 & $4-6$ & $150-225$ \\
\hline Sullivan et al. & 2014 & 1 & United States & IPCC 2007 & $\checkmark$ & $\checkmark$ & $\checkmark$ & & 30 & 20 & $4-6$ & $150-225$ \\
\hline Treyer et al. & 2014 & 1 & Switzerland & IMPACT 2002+ & & $\checkmark$ & $\checkmark$ & $\checkmark$ & 20 & 36 & 5.5 & 150 \\
\hline \multicolumn{13}{|l|}{ HT Binary ${ }^{a}$} \\
\hline Rule et al. & 2009 & 1 & New Zealand & $\mathrm{CO}_{2}$ only & $\checkmark$ & $\checkmark$ & $\checkmark$ & $\checkmark$ & 100 & 162 & 0.66 & 200 \\
\hline Sullivan et al. & 2013 & 1 & United States & IPCC 2007 & $\checkmark$ & $\checkmark$ & $\checkmark$ & & 30 & 50 & $<2$ & $150-185$ \\
\hline Sullivan et al. & 2014 & 1 & United States & IPCC 2007 & $\checkmark$ & $\checkmark$ & $\checkmark$ & & 30 & 10 & $<2$ & $150-185$ \\
\hline Martin-Gamboa et al. & 2015 & 1 & Europe & CML-IA & $\checkmark$ & $\checkmark$ & $\checkmark$ & $\checkmark$ & 25 & 2.9 & 0.725 & $150-162$ \\
\hline Heberle et al. & 2016 & 4 & Germany & Heberle et al. 2016, Table 2 & $\checkmark$ & $\checkmark$ & $\checkmark$ & $\checkmark$ & 30 & 1.75 & 3.98 & 127 \\
\hline \multicolumn{13}{|l|}{ HT Flash ${ }^{a}$} \\
\hline Hondo & 2005 & 1 & Japan & IPCC $1995\left(\mathrm{CO}_{2}\right.$ and $\left.\mathrm{CH}_{4}\right)$ & $\checkmark$ & $\checkmark$ & $\checkmark$ & & 30 & 55 & 1 & - \\
\hline Karlsdottir et al. & $2010 a$ & 1 & Iceland & CML-IA & & $\checkmark$ & $\checkmark$ & & 30 & 300 & 2.2 & 180 \\
\hline Skone et al. & 2012 & 1 & United States & IPCC 2007 & & $\checkmark$ & $\checkmark$ & & 25 & 50 & 3.2 & 182 \\
\hline Sullivan et al. & 2013 & 1 & United States & IPCC 2007 & $\checkmark$ & $\checkmark$ & $\checkmark$ & & 30 & 10 & $1.5-3$ & $175-300$ \\
\hline Sullivan et al. & 2014 & 1 & United States & IPCC 2007 & $\checkmark$ & $\checkmark$ & $\checkmark$ & & 30 & 50 & $1.5-3$ & $175-300$ \\
\hline Marchand et al. & 2015 & 3 & Guadeloupe & IPCC 2007 & $\checkmark$ & $\checkmark$ & $\checkmark$ & & 30 & 16 & $>0.5$ & $250-252$ \\
\hline Martínez-Corona et al. & 2017 & 1 & New Zealand & CML 2001 & $\checkmark$ & $\checkmark$ & $\checkmark$ & $\checkmark$ & 100 & 162 & 0.66 & 260 \\
\hline
\end{tabular}

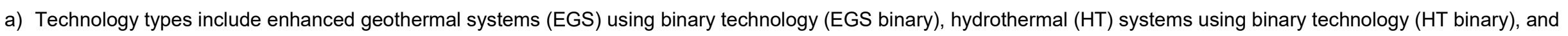
HT systems using flash technology (HT flash).

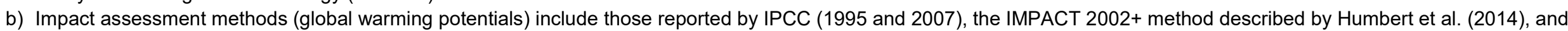
the CML-IA method from the Institute for Environmental Sciences at the University of Leiden (CML-IA 2016). The IMPACT 2002+ and the CML-IA methods both use characterization factors reported by the IPCC (2007).

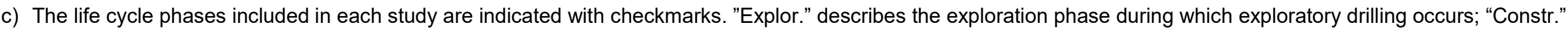

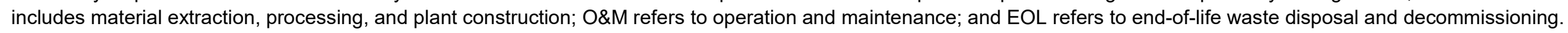

d) "Temp." refers to the temperature of the resource in the ground, not at the surface. 


\title{
Summary of Life Cycle GHG Emissions
}

Figure 1 shows the central tendency and variability of the life cycle GHG estimates from all studies that passed the first and second screens and reported life cycle GHG emissions for the three technology types examined here: EGS binary, HT flash, and HT binary (the specific studies are listed in Table 1; see Tables A-1 and A-6 in the appendix for summary statistics and raw data). By compiling results from multiple studies, this comprehensive review shows the range and distribution of values reported in the broader literature. However, it is important to note that the estimates reported here are not harmonized estimates because harmonization was outside the scope of this work. The median life cycle GHG emissions from EGS binary, HT flash, and HT binary plants were found to be 32 grams of carbon dioxide equivalent per kilowatt hour ( $\mathrm{g} \mathrm{CO}_{2}$ eq/kWh), $47 \mathrm{~g} \mathrm{CO}_{2} \mathrm{eq} / \mathrm{kWh}$, and $11.3 \mathrm{~g} \mathrm{CO}_{2} \mathrm{eq} / \mathrm{kWh}$ respectively (Figure 1; Table A-1).

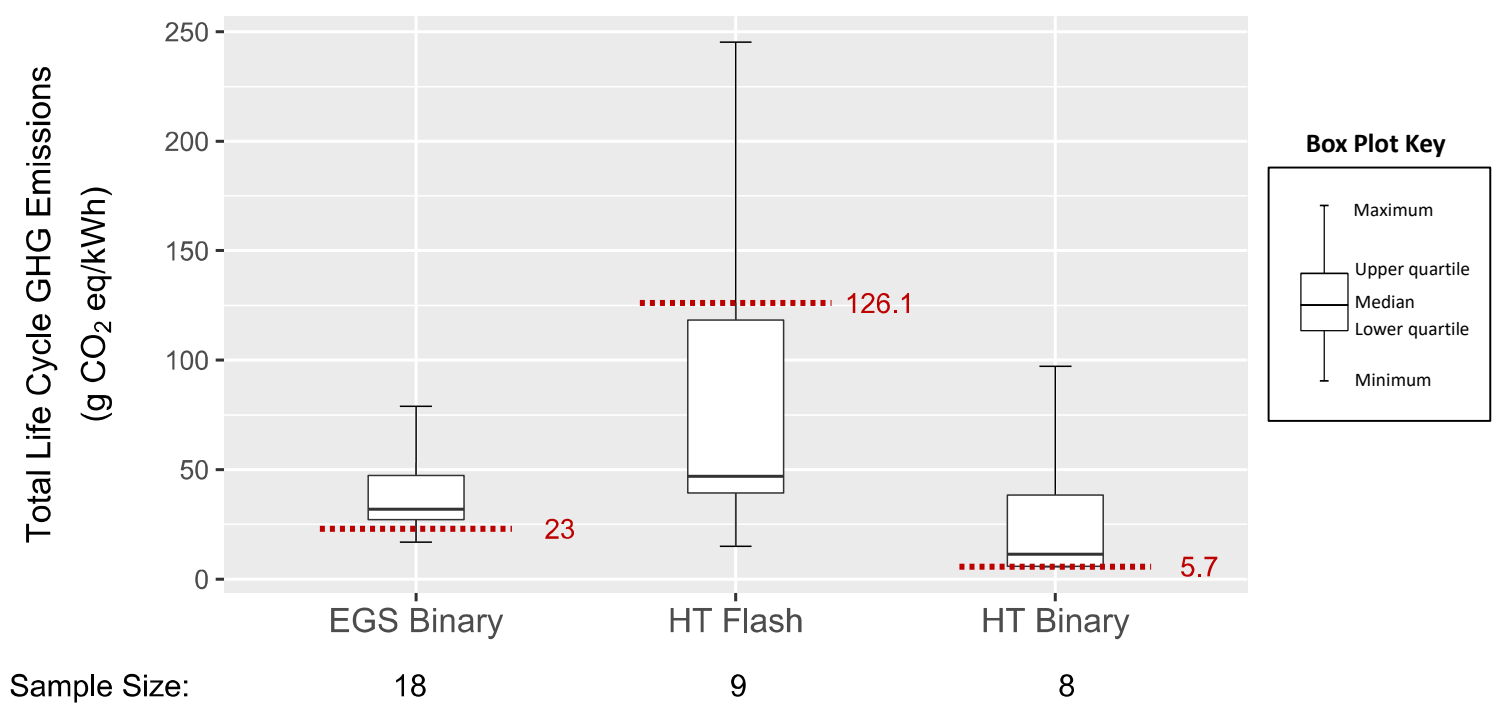

Figure 1. Side-by-side comparison of life cycle greenhouse gas (GHG) emissions from three geothermal electricity generation technologies: enhanced geothermal systems (EGS) binary, hydrothermal (HT) flash and HT binary

\begin{abstract}
Estimates from Sullivan et al. (2013) are overlaid as dashed red lines with the value for each estimate reported to the right of the line. Refer to Tables A-1 and A-6 in the appendix for summary statistics and raw estimates, respectively. Sample size refers to the number of estimates forming the box plot summary statistics for each technology. (The number of studies reporting those estimates is less than or equal to the number of estimates.)
\end{abstract}

One of the studies that we analyzed (Sullivan et al. 2013) describes the sources of geothermal GHG emission estimates that are included in Argonne National Laboratory's Greenhouse gases, Regulated Emissions, and Energy use in Transportation (GREET) model, which is used by a variety of stakeholders to evaluate emission impacts of advanced vehicle and fuel technologies. As a result, we compared the results from our literature review to the data reported by Sullivan et al. (2013) (dashed lines in Figure 1 correspond to data from Sullivan et al. [2013]). While the estimates from Sullivan et al. (2013) are within the range of estimates for all three technologies explored here, they are close to the first quartile of the literature estimates for HT binary and EGS binary and the upper quartile of the literature estimates for HT flash. Thus, there is an opportunity for updates to be made to the estimates of life cycle GHG emissions within the GREET model. 


\title{
GHG Emissions Disaggregated by Life Cycle Phase
}

Of the three geothermal electricity generation technologies examined in this report, HT flash exhibits the largest amount of variation in total life cycle GHG emissions (Figure 1). While the range for total emissions from EGS binary is $16.9-79 \mathrm{~g} \mathrm{CO}_{2} \mathrm{eq} / \mathrm{kWh}$, the range of HT flash is 15.0-245 $\mathrm{g} \mathrm{CO}_{2} \mathrm{eq} / \mathrm{kWh}$. When the emissions are disaggregated by phase, as in Figure 2, it is apparent that most of the variability in emissions from HT flash comes from plant operation, which is the largest contributor to the total emissions from HT flash plants. The large operational emissions from HT flash plants result from the release of non-condensable gases when the geofluid in a flash plant is exposed to the atmosphere after it passes through a turbine. Neither EGS binary systems nor HT binary systems have emissions associated with non-condensable gases because the geofluids in binary geothermal plants remain in a closed-loop system. However, the operational emissions associated with hydrothermal flash plants range widely depending on the efficiency of the plant and composition of the geofluid, which varies with location and depth.

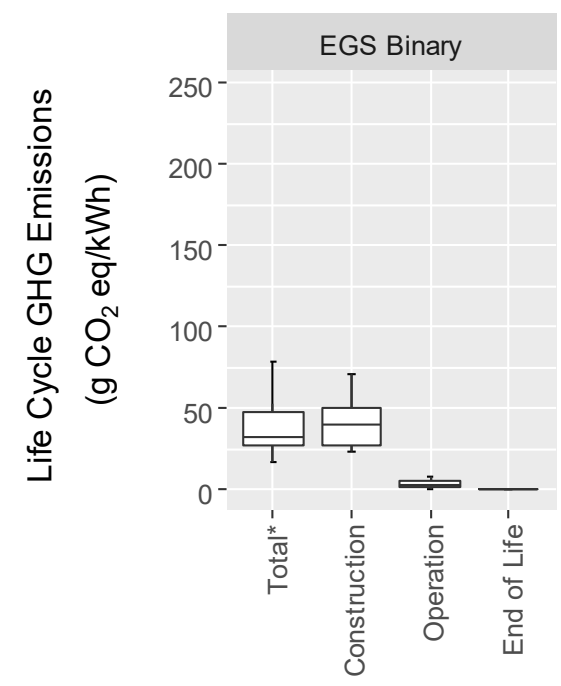

Sample Size:

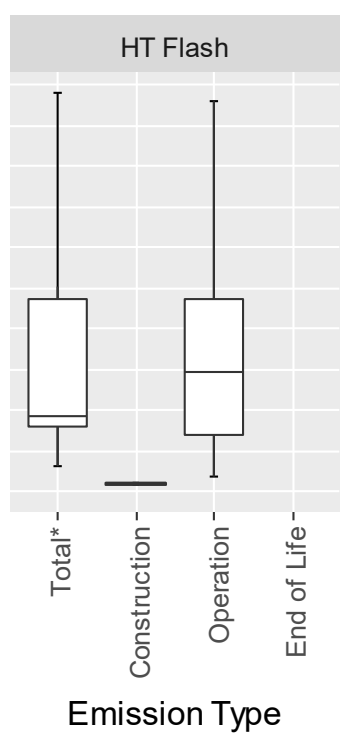

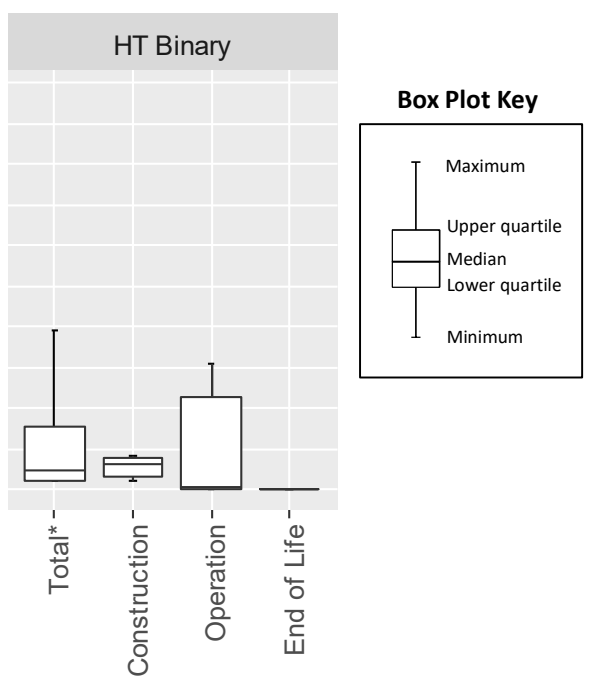

$8 \quad 6 \quad 6 \quad 4$

Figure 2. Greenhouse gas (GHG) emissions disaggregated by phase of the life cycle (i.e., total, construction, operation, and end of life) for three geothermal electricity generation technologies: enhanced geothermal systems (EGS) binary, hydrothermal (HT) flash, and HT binary.

Sample size refers to the number of estimates forming the box plot summary statistics for each technology. (The number of studies reporting those estimates is less than or equal to the number of estimates.)

\begin{abstract}
* Several studies only report estimates of total life cycle GHG emissions (they do not disaggregate emissions by phase but they do report which life cycle phases are included in their estimates of total emissions). As a result, the sample size of total life cycle GHG emission estimates is larger than the sample size of estimates disaggregated by life cycle phase (e.g., for EGS binary, the sample size of estimates for total emissions is 18 while the sample size for construction is 8 ). Since per-phase emission estimates are a subset of the estimates that provide total emission estimates and the estimates of total emissions from the per-phase and total-only sources differ, the medians of the per-phase GHG emission estimates might be greater than the median of the total.
\end{abstract}


On the other hand, construction is the major contributor to total life cycle GHG emissions from EGS binary and HT binary. Because the EGS binary wells assumed in the LCA studies are two to five times deeper than HT binary wells, they require more material for construction. EGS systems also require diesel power for the hydraulic stimulation and often involve more production and injection wells (Sullivan et al. 2014). Thus, the emissions from the construction of EGS binary plants are much higher than those for HT binary plants.

\section{Importance of Operational Emissions}

Several of the geothermal LCA studies we reviewed discussed the large contribution of and the variability associated with the operational emissions from HT flash plants (Sullivan et al. 2011; Sullivan et al. 2012; Sullivan et al. 2013; Sullivan and Wang 2013; and Sullivan et al. 2014). In particular, these studies referenced a survey conducted by Bertani and Thain (2002) to assess the worldwide operational emissions from HT flash plants. From this survey, Bertani and Thain reported a weighted average of 122 grams of carbon dioxide per kilowatt hour $\left(\mathrm{g} \mathrm{CO}_{2} / \mathrm{kWh}\right)$ and a range of $4-740 \mathrm{~g} \mathrm{CO}_{2} / \mathrm{kWh}$ for operational emissions from geothermal electricity. Even without including the emissions from other types of GHGs, such as methane and nitrous oxide, the maximum amount of carbon dioxide reportedly emitted (in grams per kilowatt hour) is greater than some estimates for the total GHG emissions from natural gas power plants; the median of harmonized estimates of life cycle GHG emissions for electricity generated by a natural gas combustion turbine is $450 \mathrm{~g} \mathrm{CO}_{2} \mathrm{eq} / \mathrm{kWh}$ (O'Donoughue et al. 2014).

Many of the studies we reviewed also discuss the variability in operational emissions from flash plants in California (Sullivan et al. 2011, 2012, 2013, 2014; Sullivan and Wang 2013). For example, Sullivan et al. (2014) collected data from the California Environmental Protection Agency and found that the operational GHG emissions from HT flash plants in California had a weighted average of $103 \mathrm{~g} \mathrm{CO}_{2} \mathrm{eq} / \mathrm{kWh}$ in 2012 , with $85 \%$ of the plants emitting below $170 \mathrm{~g}$ $\mathrm{CO}_{2} \mathrm{eq} / \mathrm{kWh}$ and only two plants emitted more than $300 \mathrm{~g} \mathrm{CO}_{2} \mathrm{eq} / \mathrm{kWh}$.

To better describe how the emissions from actual geothermal power plants compare with the GHG emissions computed from the LCA studies we reviewed, we compiled data from four studies reporting operational emissions from actual power plants: Bertani and Thain (2002), Holm et al. (2012), Sullivan and Wang (2013), and Bravi and Basosi (2014). The results of this review are illustrated in the left column of Figure 3, which shows the range of operational emissions from geothermal power plants, most of which use HT flash technology. Rather than reporting total GHG emissions, these four studies only describe emissions from one GHG, carbon dioxide because this is the only GHG for which operational emissions are reported. 


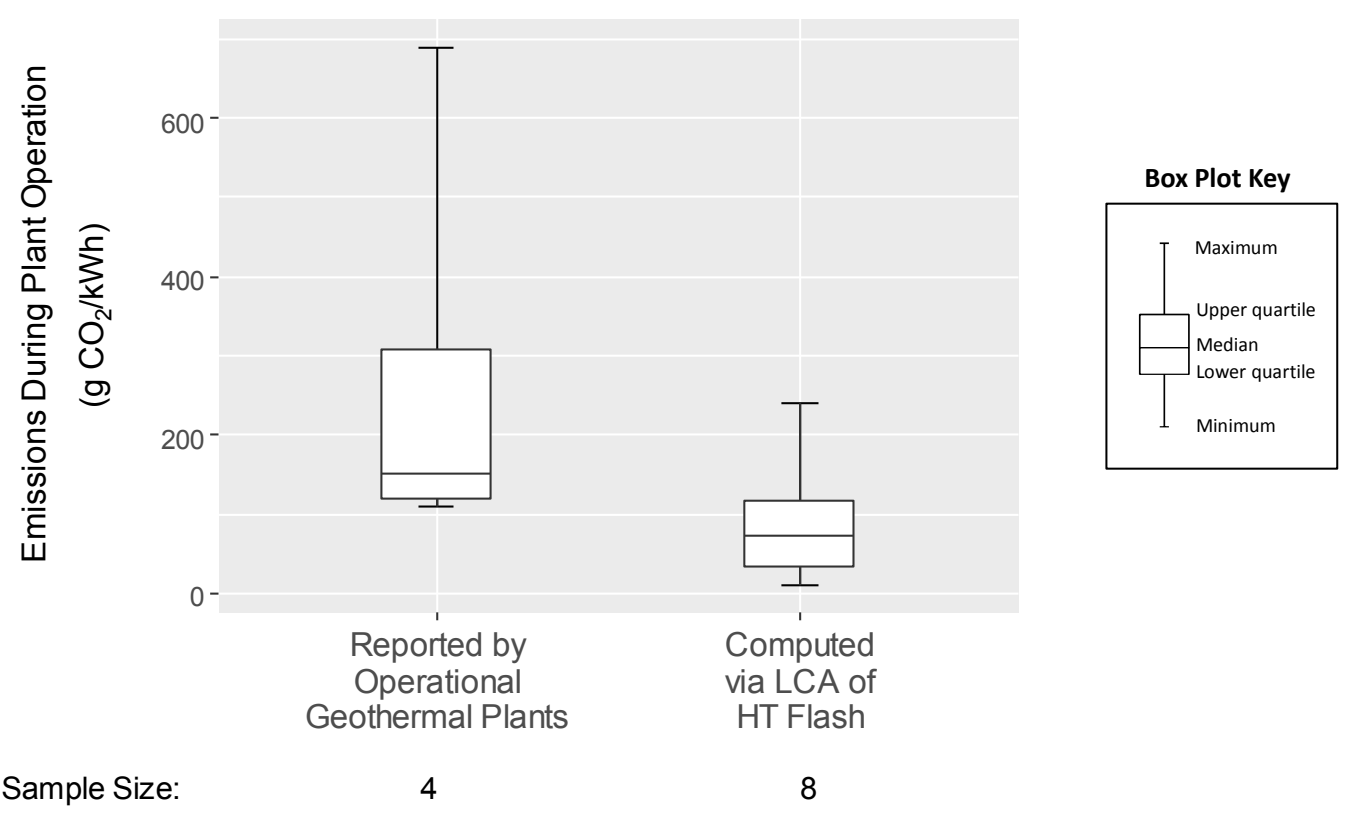

Figure 3. Comparison of carbon dioxide $\left(\mathrm{CO}_{2}\right)$ emissions reported by operational geothermal plants (compiled from Bertani and Thain 2002, Holm et al. 2012, Sullivan and Wang 2013, and Bravi and Basosi 2014) versus GHG emissions computed from life cycle assessments (LCAs) of electricity generated by hydrothermal (HT) flash plants (same values as reported in Figures 1 and 2 above).

\begin{abstract}
Sample size refers to the number of estimates forming the box plot summary statistics for each technology. (The number of studies reporting those estimates is less than or equal to the number of estimates.)
\end{abstract}

It is clear from these studies that operational emissions from geothermal flash plants vary widely and may be up to ten times greater than those estimated from the LCA studies examined here. However, because the amount of non-condensable gases emitted during operation varies with multiple parameters, including geographic location, well depth, and resource temperature, and these system characteristics differ across the LCA studies and the operational studies, one would need to ensure a consistent set of system characteristics in order to perform a fair comparison of the emissions reported from operational studies and LCAs. Such a comparative analysis is beyond the scope of this work but more research needs to be done to quantify the relationships among resource location, geofluid composition, and GHG emissions. Furthermore, because most flash power plants are located in areas where natural geothermal resources (e.g., hot springs and geysers) already occur and because these areas may have a background level of GHGs from "natural" emissions, identifying the emissions of anthropogenic geothermal systems could be difficult. Thus, more work also needs to be done to identify the difference between natural and geothermal electricity-induced GHG emissions. 


\section{Conclusions}

We performed a systematic review of the LCA literature on geothermal energy, evaluating the quality, completeness, transparency, and relevance of over 180 geothermal environmental impact studies. We identified 29 LCA studies on geothermal energy that passed our rigorous screening methodology. These studies included assessments for the GHG emissions and water use associated with geothermal electricity generation, heat generation, and combined heat and power. We then examined three electricity generation technologies (i.e., EGS binary, HT binary, and HT flash) in detail and compiled published estimates for life cycle GHG emissions.

There are several limitations of this work. First, we only examine the GHG emissions associated with three geothermal technologies that generate electricity. There are other types of geothermal technologies, including those that produce heat for heating purposes, that could be addressed in future research. Second, the results presented here only represent an examination of one environmental impact category: climate change (as measured by life cycle GHG emissions). Numerous other impact categories, such human toxicity, land use, and resource consumption would need to be examined to gain a more comprehensive understanding of the life cycle environmental impacts of geothermal electricity. Third, the results presented here do not represent the distribution of likelihood for actual life cycle GHG emissions from geothermal electricity. As evidenced by the comparison of operational emissions, the results compiled from these LCAs may not represent all possible variations in parameters associated with geothermal energy. Finally, the results presented here are published estimates, not adjusted for consistency in methods or underlying assumptions, as has been completed for many other generation technologies in NREL's LCA Harmonization Project. There are several inconsistencies among the estimates that we compiled for life cycle GHG emissions. For example, these studies comprise a wide variety of geographic regions, well depths, and temperatures; they also use different impact assessment methods, characterization factors, operating lifetimes, and system boundaries. A complete harmonization of these studies would provide a more consistent estimate of central tendency for life cycle GHG emissions of these geothermal generation technologies.

Despite these limitations, our analysis revealed that, of the three geothermal electricity generation technologies considered, HT flash generates the most GHG emissions per kilowatt hour of electricity (median of $47 \mathrm{~g} \mathrm{CO}_{2} \mathrm{eq} / \mathrm{kWh}$ ). These median $\mathrm{GHG}$ emissions from HT flash were nearly $50 \%$ greater than the median for EGS binary and over four times greater than median for HT binary. Furthermore, while most of the GHG emissions from HT binary and EGS binary are associated with the construction of these technologies, GHG emissions from HT flash primarily result from operation of the facility. These operational emissions result from the openloop nature of HT flash technology, which releases non-condensable gases when the geofluid is exposed to the atmosphere.

The variability in operational GHG emissions from geothermal power plants presents a challenging problem for computing the technology's impact on climate change. We show that the median $\mathrm{CO}_{2}$ emissions reported by operational geothermal plants are approximately two times larger than the median LCA estimates of GHG emissions from the operation of HT flash plants. Because the operational emissions of geothermal plants vary widely with system characteristics (e.g., local geology, depth, temperature), the differences in operational emissions reported by LCAs and operational studies are likely a result of differences in the system 
characteristics that are used in these studies. A better understanding of the distribution of noncondensable gases in geothermal reservoirs, as well as the effects of reservoir depletion and repressurization on GHG emissions profiles over time, would improve estimates of life cycle GHG emissions from geothermal plants.

Overall, we show that there are large variations in the life cycle GHG emissions from three types of geothermal technologies that generate electricity: HT flash, HT binary, and EGS binary. The median estimates for HT binary and EGS binary technologies generate less than $40 \mathrm{~g} \mathrm{CO}_{2}$ $\mathrm{eq} / \mathrm{kWh}$, which represents the same order as most other renewable energy technologies (IPCC 2011). However, the median value in the literature for HT flash is slightly higher $\left(47 \mathrm{~g} \mathrm{CO}_{2}\right.$ $\mathrm{eq} / \mathrm{kWh}$ ), and the range of literature and operational emissions from this technology indicate it may generate three to ten times more GHG emissions than other renewable energy technologies. Because EGSs are still in the development and demonstration phase, the estimate for GHG emissions from EGS binary might change once the technology is commercialized. On the other hand, HT binary is a more mature technology than EGS binary and appears to have the lowest life cycle GHG emissions of the three types of geothermal electricity generation technologies examined here. 


\section{References}

Bauer, C., R. Dones, T. Heck, and S. Hirschberg. 2008. "Environmental Assessment of Current and Future Swiss Electricity Supply Options." International Conference on the Physics of Reactors (2008) Nuclear Power: A Sustainable Resource. Interlaken, Switzerland.

Bertani, R., and I. Thain. 2002. "Geothermal Power Generating Plant CO2 Emission Survey." International Geothermal Association Newsletter 49 (July-September 2002): 1-3.

Bertani, R. 2016. "Geothermal Power Generation in the World 2010-2014 Update Report." Geothermics 60 (2016): 31-43.

Bravi, M., and R. Basosi. 2014. "Environmental Impact of Electricity from Selected Geothermal Power Plants in Italy.” Journal of Cleaner Production 66 (2014): 301-308.

Buonocore, Elvira, Laura Vanoli, Alberto Carotenuto, and Sergio Ulgiati. 2015. "Integrating Life Cycle Assessment and Energy Synthesis for the Evaluation of a Dry Steam Geothermal Power Plant in Italy.” Energy 86 (June 15, 2015): 476-87. doi:10.1016/j.energy.2015.04.048.

Burgassi, P.D. 1999. "Historical Outline of Geothermal Technology in the Larderello Region to the Middle of the 20th Century." In Stories from a Heated Earth. R. Cataldi, S. Hodgson and J.W. Lund (eds.), pp. 195-219. Sacramento, CA Geothermal Resources Council and International Geothermal Association. ISBN: 0934412197.

Cataldi, R. 1999. "The Year Zero of Geothermics." In Stories from a Heated Earth. R. Cataldi, S. Hodgson and J.W. Lund (eds.), pp. 7-17. Sacramento, CA Geothermal Resources Council and International Geothermal Association. ISBN: 0934412197.

Clark, C., C. Harto, J. Sullivan, and M. Wang. 2011. Water Use in the Development and Operation of Geothermal Power Plants. Environmental Science Division, Argonne National Laboratory. ANL/EVS/R-10/5.

Clark, C.E., C.B. Harto, J.N. Schroeder, L.E. Martino, and R.M. Horner. 2013. Life Cycle Water Consumption and Water Resource Assessment for Utility-Scale Geothermal Systems: An InDepth Analysis of Historical and Forthcoming EGS Projects. Environmental Science Division, Argonne National Laboratory. ANL/EVS/R-12/8.

CML-IA. 2016. “Characterisation Factors.” Institute of Environmental Sciences (CML), University of Leiden. September 5, 2016. http://www.cml.leiden.edu/software/data-cmlia.html.

DOE (U.S. Department of Energy). 2004. "Geothermal Technologies Program: Enhanced Geothermal Systems.” DOE/GO-102004-1958. http://www.nrel.gov/docs/fy04osti/36317.pdf.

DOE (U.S. Department of Energy). 2015. Wind Vision. Washington, DC. http://www.energy.gov/windvision.

DOE (U.S. Department of Energy). 2016. Hydropower Vision. Washington, DC. https://energy.gov/eere/water/articles/hydropower-vision-new-chapter-america-s-1st-renewableelectricity-source 
EIA (U.S. Energy Information Administration). 2016. "International Energy Outlook 2016." https://www.eia.gov/outlooks/ieo/pdf/0484(2016).pdf

Frick, S., M. Kaltschmitt, and G. Schroder. 2010. "Life Cycle Assessment of Geothermal Binary Power Plants Using Enhanced Low-Temperature Reservoirs." Energy 35 (5, May 2010): 228194. doi:10.1016/j.energy.2010.02.016.

Genchi, Yutaka, Yukihiro Kikegawa, and Atsushi Inaba. 2002. "CO2 Payback-Time Assessment of a Regional-Scale Heating and Cooling System Using a Ground Source Heat-Pump in a High Energy-Consumption Area in Tokyo." Applied Energy 71 (3, March 2002): 147-60. doi:10.1016/S0306-2619(02)00010-7.

Ghafghazi, Saeed, Taraneh Sowlati, Shahab Sokhansanj, Xiaotao Bi, and Staffan Melin. 2011. "Life Cycle Assessment of Base-load Heat Sources for District Heating System Options." International Journal of Life Cycle Assessment 16 (3, February 22, 2011): 212-23. doi:10.1007/s11367-011-0259-9.

Gilli, P.V., W. Streicher, H. Halozan, and G. Beembroek. 1999. "Environmental Benefits of Heat Pumping Technologies." ARGE Waermetechnik, Graz, Austria EA Heat Pump Centre, Sittard, Netherlands.

Heberle, F., C. Schifflechner, and D. Brüggemann. 2016. "Life Cycle Assessment of Organic Rankine Cycles for Geothermal Power Generation Considering Low-GWP Working Fluids." Geothermics 64 (2016): 392-400.

Heath, G. A., and M. K. Mann. 2012. "Background and Reflections on the Life Cycle Assessment Harmonization Project." Journal of Industrial Ecology, 16: S8-S11. doi: 10.1111/j.1530-9290.2012.00478.x

Holm, A., D. Jennejohn, and L. Blodgett. 2012. "Geothermal Energy Reduces Greenhouse Gas Emissions." Geothermal Energy Association (November 2012). http://www.geoenergy.org/reports/GeothermalGreenhouseEmissionsNov2012GEA web.pdf.

Hondo, Hiroki. 2005. "Life Cycle GHG Emission Analysis of Power Generation Systems: Japanese Case.” Energy 30 (11-12, SPEC ISS, 2005): 2042-56.

Humbert, S., A.D. Schyver, X. Bengoa, M. Margni, and O. Jolliet. 2014. Impact 2002+ User Guide. http://www.quantis-intl.com/files/8814/1198/3664/ IMPACT2002_UserGuide_for_vQ2.21_30April2014a.pdf.

IPCC (Intergovernmental Panel on Climate Change). 1995. Climate Change 1995: The Science of Climate Change. J.T. Houghton, M. Filho, B.A. Callander, N. Harris, A. Kattenberg, K. Maskell, and J.A. Lakeman (eds). Cambridge University Press, Cambridge, United Kingdom, and New York, NY. http://www.ipcc.ch/ipccreports/sar/wg_I/ipcc_sar_wg_I_full_report.pdf.

2007. Climate Change 2007: The Physical Science Basis. S. Solomon, D. Qin, M. Manning, Z. Chen, M. Marquis, K.B. Averyt, M. Tignor and H.L. Miller (eds.). Cambridge University Press, Cambridge, United Kingdom, and New York, NY. pp. 996 
- 2011. IPCC Special Report on Renewable Energy Sources and Climate Change Mitigation. Prepared by Working Group III of the Intergovernmental Panel on Climate Change. O. Edenhofer, R. Pichs-Madruga, Y. Sokona, K. Seyboth, P. Matschoss, S. Kadner, T. Zwickel, P. Eickemeier, G. Hansen, S. Schlömer, C. von Stechow (eds). Cambridge University Press, Cambridge, United Kingdom, and New York, NY. pp. 1075

ISO. 2006. Environmental Management - Life Cycle Assessment - Principles and Framework. International Organization for Standardization 14040. Geneva, Switzerland: ISO.

Karlsdottir, M. R., O. P. Palsson, and H. Palsson. 2010a. "Factors for Primary Energy Efficiency and CO2 Emission of Geothermal Power Production," in Proc. World Geothermal Congress (April 2010).

- 2010b. "LCA of Combined Heat and Power Production at Hellisheidi Geothermal Power Plant with Focus on Primary Energy Efficiency," 12th International Symposium on District Heating and Cooling (2010): 184-92. http://www.scopus.com/inward/record.url?eid=2s2.0-79952655547\&partnerID=40\&md5=c9dcdc94bc943f0568faf8a2addf9aee.

Kim, J., T. Hong, M. Chae, C. Koo, and J. Jeong. 2015. “An Environmental and Economic Assessment for Selecting the Optimal Ground Heat Exchanger by Considering the Entering Water Temperature." Energies 8 (2015): 7752-76. doi:10.3390/en8087752.

Lacirignola, Martino, and Isabelle Blanc. 2013. "Environmental Analysis of Practical Design Options for Enhanced Geothermal Systems (EGS) through Life-Cycle Assessment." Renewable Energy 50 (February 2013): 901-14. doi:10.1016/j.renene.2012.08.005.

Lund, J.W., and T.L. Boyd. 2016. "Direct utilization of geothermal energy 2015 worldwide review." Geothermics 60: 66-93.

Marchand, M., I. Blanc, A. Marquand, A. Beylot, S. Bezelgues-Courtade, and H. Traineau. 2015. "Life Cycle Assessment of High Temperature Geothermal Energy Systems," in Proc. World Geothermal. Congress, Melbourne, Australia, 2015.

Martínez-Corona, J. I., T. Gibon,E. G. Hertwich, and R. Parra-Saldívar. 2017. "Hybrid Life Cycle Assessment of a Geothermal Plant: From Physical to Monetary Inventory Accounting." Journal of Cleaner Production 142 (2017): 2509-2523.

Martin-Gamboa, Mario, Diego Iribarren, and Javier Dufour. 2015. "On the Environmental Suitability of High- and Low-Enthalpy Geothermal Systems.” Geothermics 53 (January 2015): 27-37. doi:10.1016/j.geothermics.2014.03.012.

Mattinen, Maija K., Ari Nissinen, Sampsa Hyysalo, and Jouni K. Juntunen. 2015. "Energy Use and Greenhouse Gas Emissions of Air-Source Heat Pump and Innovative Ground-Source Air Heat Pump in a Cold Climate." Journal of Industrial Ecology 19, (1, February 2015): 61-70. doi:10.1111/jiec.12166.

Meldrum, J., S. Nettles-Anderson, G. Heath, and J. Macknick. 2013. "Life Cycle Water Use for Electricity Generation: A Review and Harmonization of Literature Estimates." Environmental Research Letters 8 (1, 2013). doi:10.1088/1748-9326/8/1/015031. 
O’Donoughue, P.R., G.A. Heath, S.L. Dolan, and M. Vorum. 2014. "Life Cycle Greenhouse Gas Emissions of Electricity Generated from Conventionally Produced Natural Gas: Systematic Review and Harmonization." Journal of Industrial Ecology 18 (January 2014): 125-144.

Ristimäki, M., A. Säynäjoki, J. Heinonen, and S. Junnila. 2013. “Combining Life Cycle Costing and Life Cycle Assessment for an Analysis of a New Residential District Energy System Design.” Energy 63 (2013): 168-79. doi:10.1016/j.energy.2013.10.030.

Rogge, S., and M. Kaltschmitt. 2003. "Electricity and Heat Production from Geothermal Energy: An Ecologic Comparison.” Erdoel Erdgas Kohle/EKEP 119 (1, January 2003): 35-40.

Rule, B.M., Z.J. Worth, and C.A. Boyle. 2009. "Comparison of Life Cycle Carbon Dioxide Emissions and Embodied Energy in Four Renewable Electricity Generation Technologies in New Zealand." Environmental Science \& Technology 43 (16, August 15, 2009): 6406-13. doi:10.1021/es900125e.

Russo, Giovanni, Alexandros S. Anifantis, and Giacomo Scarascia Mugnozza. "Environmental Analysis of Geothermal Heat Pump and LPG Greenhouse Heating Systems." Biosystems Engineering 127 (November 2014): 11-23. doi:10.1016/j.biosystemseng.2014.08.002.

Ruzzenenti, Franco, Mirko Bravi, Duccio Tempesti, Enrica Salvatici, Giampaolo Manfrida, and Riccardo Basosi. 2014. "Evaluation of the Environmental Sustainability of a Micro CHP System Fueled by Low-Temperature Geothermal and Solar Energy." Energy Conversion and Management 78 (February 2014): 611-16. doi:10.1016/j.enconman.2013.11.025.

Saner, Dominik, Ronnie Juraske, Markus Kübert, Philipp Blum, Stefanie Hellweg, and Peter Bayer. 2010. "Is It Only CO2 That Matters? A Life Cycle Perspective on Shallow Geothermal Systems." Renewable and Sustainable Energy Reviews 14 (7, September 2010): 1798-1813.

Skone, Timothy J., James Littlefield, Robert Eckard, Greg Cooney, and Joe Marriott. 2012. "Role of Alternative Energy Sources: Geothermal Technology Assessment." U.S. National Energy Technology Laboratory, August 28, 2012. http://netl.doe.gov/energyanalyses/pubs/GeothermalTARNETL.pdf.

Sullivan, J. L., C. Clark, J. Han, and M. Wang. 2010. "Life-Cycle Analysis Results of Geothermal Systems in Comparison to Other Power Systems." Argonne National Laboratory.

Sullivan, J. L., C. Clark, J. Han, C. Harto, and M. Wang. 2013.“Cumulative Energy, Emissions, and Water Consumption for Geothermal Electric Power Production." Journal of Renewable and Sustainable Energy 5 (2, March 1, 2013): 023127. doi:10.1063/1.4798315.

Sullivan, J. L., and M. Q. Wang. 2013. "Life Cycle Greenhouse Gas Emissions from Geothermal Electricity Production." Journal of Renewable and Sustainable Energy 5 (6, November 2013): 063122. doi:10.1063/1.4841235.

Sullivan, J. L., T. Stephens, and M. Wang. 2014. "Geothermal Power Production: Alternative Scenarios and Critical Issues.” Argonne National Laboratory (ANL). http://www.osti.gov/scitech/biblio/1132252-geothermal-power-production-alternative-scenarioscritical-issues. 
Treyer, K., C. Bauer, and A. Simons. 2014. "Human Health Impacts in the Life Cycle of Future European Electricity Generation.” Energy Policy 74 (suppl. 1, December 2014):S31-S44. doi: 10.1016/j.enpol.2014.03.034. 


\section{Appendix. Supplementary Material}

Table A-1. Total Life Cycle GHG Emissions from Three Types of Geothermal Electricity: EGS Binary, HT Binary, and HT Flash ${ }^{a}$

\begin{tabular}{|lcccc|}
\hline Min $\left(\mathrm{g} \mathrm{CO}_{2} \mathrm{eq} / \mathrm{kWh}\right)$ & EGS Binary & HT Flash & HT Binary & All Technologies \\
\hline Quartile $1\left(\mathrm{~g} \mathrm{CO}_{2} \mathrm{eq} / \mathrm{kWh}\right)$ & 16.9 & 15.0 & 5.6 & 5.6 \\
\hline Median $\left(\mathrm{g} \mathrm{CO}_{2} \mathrm{eq} / \mathrm{kWh}\right)$ & 27.2 & 39.4 & 5.8 & 21.9 \\
\hline Quartile 3 $\left(\mathrm{g} \mathrm{CO}_{2} \mathrm{eq} / \mathrm{kWh}\right)$ & 32.0 & 47.0 & 11.3 & 36.7 \\
\hline Max $\left(\mathrm{g} \mathrm{CO}_{2}\right.$ eq/kWh) & 47.5 & 118.4 & 38.5 & 51.5 \\
\hline Sample size & 79.0 & 245.2 & 97.2 & 245.2 \\
\hline
\end{tabular}

a) These values were computed from the estimates obtained from the studies that passed both of our literature screens. EGS Binary = enhanced geothermal systems used in the operation of binary cycle power plants, HT binary = hydrothermal (HT) resources used in binary cycle plants, and HT flash = high temperature HT resources that are vaporized in flash steam plants.

Table A-2. GHG Emissions from the Construction Phase of Three Types of Geothermal Electricity: EGS Binary, HT Binary, and HT Flash ${ }^{\mathrm{a}}$

\begin{tabular}{|lcccc|} 
& EGS Binary & HT Flash & HT Binary & All Technologies \\
\hline Min $\left(\mathrm{g} \mathrm{CO}_{2}\right.$ eq/kWh) & 23.0 & 3.9 & 5.7 & 3.9 \\
\hline Quartile 1 $\left(\mathrm{g} \mathrm{CO}_{2}\right.$ eq/kWh) & 27.7 & 4.1 & 8.0 & 5.2 \\
\hline Median $\left(\mathrm{g} \mathrm{CO}_{2}\right.$ eq/kWh) & 39.9 & 5.0 & 15.0 & 15.3 \\
\hline Quartile 3 $\left(\mathrm{g} \mathrm{CO}_{2} \mathrm{eq} / \mathrm{kWh}\right)$ & 50.2 & 5.1 & 19.1 & 27.7 \\
\hline Max $\left(\mathrm{g} \mathrm{CO}_{2} \mathrm{eq} / \mathrm{kWh}\right)$ & 71.1 & 5.3 & 20.5 & 71.1 \\
\hline Sample size & 8 & 7 & 6 & 21 \\
\hline
\end{tabular}

a) These values were computed from the estimates obtained from the studies that passed both of our literature screens. EGS Binary = enhanced geothermal systems used in the operation of binary cycle power plants, HT binary = hydrothermal (HT) resources used in binary cycle plants, and HT flash = high temperature HT resources that are vaporized in flash steam plants.

Table A-3 GHG Emissions from the Operation Phase of Three Types of Geothermal Electricity: EGS Binary, HT Binary, and HT Flash ${ }^{\mathrm{a}}$

\begin{tabular}{|lcccc|}
\hline Min $\left(\mathrm{g} \mathrm{CO}_{2}\right.$ eq/kWh) & 0.0 & 9.7 & 0.0 & All Technologies \\
\hline Quartile $1\left(\mathrm{~g} \mathrm{CO}_{2}\right.$ eq $\left./ \mathrm{kWh}\right)$ & 1.0 & 34.6 & 0.7 & 0.0 \\
\hline Median $\left(\mathrm{g} \mathrm{CO}_{2}\right.$ eq/kWh) & 2.5 & 73.2 & 0.9 & 1.0 \\
\hline Quartile $3\left(\mathrm{~g} \mathrm{CO}_{2}\right.$ eq $\left./ \mathrm{kWh}\right)$ & 5.4 & 118.3 & 56.1 & 5.9 \\
\hline Max $\left(\mathrm{g} \mathrm{CO}_{2}\right.$ eq $\left./ \mathrm{kWh}\right)$ & 7.5 & 240.2 & 76.8 & 240.2 \\
\hline Sample size & 8 & 8 & 7 & 23 \\
\hline
\end{tabular}

a) These values were computed from the estimates obtained from the studies that passed both of our literature screens. EGS Binary = enhanced geothermal systems used in the operation of binary cycle power plants, HT binary = hydrothermal (HT) resources used in binary cycle plants, and HT flash = high temperature HT resources that are vaporized in flash steam plants. 
Table A-4. GHG Emissions from the End of Life Phase of Three Types of Geothermal Electricity: EGS Binary, HT Binary, and HT Flash ${ }^{\mathrm{a}}$

\begin{tabular}{|lllll|} 
& EGS Binary & HT Flash & HT Binary & All Technologies \\
\hline Min $\left(\mathrm{g} \mathrm{CO}_{2}\right.$ eq/kWh) & 0.15 & - & 0.04 & 0.04 \\
\hline Quartile $1\left(\mathrm{~g} \mathrm{CO}_{2}\right.$ eq/kWh) & 0.16 & - & 0.04 & 0.07 \\
\hline Median $\left(\mathrm{g} \mathrm{CO}_{2}\right.$ eq/kWh) & 0.21 & - & 0.06 & 0.12 \\
\hline Quartile 3 $\left(\mathrm{g} \mathrm{CO}_{2}\right.$ eq $\left./ \mathrm{kWh}\right)$ & 0.29 & - & 0.08 & 0.18 \\
\hline Max $\left(\mathrm{g} \mathrm{CO}_{2}\right.$ eq/kWh) & 0.40 & - & 0.08 & 0.40 \\
\hline Sample size & 4 & - & 4 & 8 \\
\hline
\end{tabular}

a) These values were computed from the estimates obtained from the studies that passed both of our literature screens. EGS Binary = enhanced geothermal systems used in the operation of binary cycle power plants, HT binary = hydrothermal (HT) resources used in binary cycle plants, and $\mathrm{HT}$ flash $=$ high temperature $\mathrm{HT}$ resources that are vaporized in flash steam plants.

Table A-5. $\mathrm{CO}_{2}$ Emissions from the Operation Phase of Active Geothermal Plants Compared to GHG Emissions Computed via LCA of HT Flash Technologya

\begin{tabular}{|lcc|} 
& $\begin{array}{c}\mathrm{CO}_{2} \text { Emissions } \\
\text { Reported by } \\
\text { Operational Plants }\end{array}$ & $\begin{array}{c}\text { GHG Emissions } \\
\text { Computed via } \\
\text { LCA of HT Flash }\end{array}$ \\
\hline Min $\left(\mathrm{g} \mathrm{CO}_{2} \mathrm{eq} / \mathrm{kWh}\right)$ & 110.0 & 9.7 \\
\hline Quartile $1\left(\mathrm{~g} \mathrm{CO}_{2} \mathrm{eq} / \mathrm{kWh}\right)$ & 119.0 & 34.6 \\
\hline Median $\left(\mathrm{g} \mathrm{CO}_{2} \mathrm{eq} / \mathrm{kWh}\right)$ & 151.0 & 73.2 \\
\hline Quartile 3 $\left(\mathrm{g} \mathrm{CO}_{2} \mathrm{eq} / \mathrm{kWh}\right)$ & 307.6 & 118.3 \\
\hline Max $\left(\mathrm{g} \mathrm{CO}_{2} \mathrm{eq} / \mathrm{kWh}\right)$ & 690.2 & 240.2 \\
\hline Sample size & 4 & 8 \\
\hline
\end{tabular}

a) Emissions from operational plants were compiled from Bertani and Thain (2002), Holm et al. (2012), Sullivan and Wang (2013), and Bravi and Basosi (2014). GHG emissions computed via LCA were obtained from the studies that passed both of our literature screens (see Column 3 of Table A-3). The data in Table A-5 were used to generate Figure 3. 
Table A-6. Life Cycle GHG Estimates from the 29 Studies that Passed both Rounds of Screening

\begin{tabular}{|c|c|c|c|c|c|c|}
\hline \multirow{2}{*}{ Author(s) } & \multirow{2}{*}{ Year } & \multirow{2}{*}{ Technology } & \multicolumn{4}{|c|}{ Emissions (g CO${ }_{2} \mathrm{eq} / \mathrm{kWh}$ ) } \\
\hline & & & Total & Constr. & Oper. & EOL \\
\hline Rule et al. & 2009 & HT binary & 5.6 & - & - & - \\
\hline Sullivan et al. & 2013 & HT binary & 5.7 & 5.7 & 0 & - \\
\hline Martin-Gamboa et al. & 2015 & HT binary & 5.79 & - & - & - \\
\hline Sullivan et al. & 2014 & HT binary & 6.4 & 5.7 & 0.72 & - \\
\hline Heberle et al. & 2016 & HT binary & 89.2 & 14.7 & 74.4 & 0.04 \\
\hline Heberle et al. & 2016 & HT binary & 16.1 & 15.3 & 0.8 & 0.04 \\
\hline Heberle et al. & 2016 & HT binary & 97.2 & 20.3 & 76.8 & 0.08 \\
\hline Heberle et al. & 2016 & HT binary & 21.6 & 20.5 & 1 & 0.08 \\
\hline Lacirignola and Blanc & 2013 & EGS binary & 16.9 & - & - & - \\
\hline Lacirignola and Blanc & 2013 & EGS binary & 21.8 & - & - & - \\
\hline Lacirignola and Blanc & 2013 & EGS binary & 22 & - & - & - \\
\hline Treyer et al. & 2014 & EGS binary & 24 & 23 & 1 & - \\
\hline Bauer et al. & 2008 & EGS binary & 27 & - & - & - \\
\hline Sullivan et al. & 2013 & EGS binary & 27.7 & 27.7 & 0 & - \\
\hline Lacirignola and Blanc & 2013 & EGS binary & 28.6 & - & - & - \\
\hline Lacirignola and Blanc & 2013 & EGS binary & 29.2 & - & - & - \\
\hline Lacirignola and Blanc & 2013 & EGS binary & 29.3 & - & - & - \\
\hline Sullivan et al. & 2014 & EGS binary & 34.6 & 27.7 & 6.89 & - \\
\hline Lacirignola and Blanc & 2013 & EGS binary & 36.7 & 33.03 & 3.67 & - \\
\hline Lacirignola and Blanc & 2013 & EGS binary & 37.9 & - & - & - \\
\hline Lacirignola and Blanc & 2013 & EGS binary & 40.4 & - & - & - \\
\hline Lacirignola and Blanc & 2013 & EGS binary & 49.8 & - & - & - \\
\hline Frick et al. & 2010 & EGS binary & 51 & 49.827 & 1.02 & 0.153 \\
\hline Rogge and Kaltschmitt & 2003 & EGS binary & 52 & 46.8 & 4.94 & 0.26 \\
\hline Frick et al. & 2010 & EGS binary & 53 & 51.516 & 1.325 & 0.159 \\
\hline Rogge and Kaltschmitt & 2003 & EGS binary & 79 & 71.1 & 7.505 & 0.395 \\
\hline Karlsdottir et al. & $2010 a$ & HT flash & 40 & - & - & - \\
\hline Hondo & 2005 & HT flash & 15 & 5.3 & 9.7 & - \\
\hline Sullivan et al. & 2014 & HT flash & 109 & 4.1 & 104.51 & - \\
\hline Sullivan et al. & 2013 & HT flash & 126.1 & 4.1 & 122 & - \\
\hline Skone et al. & 2012 & HT flash & 245.2 & 5 & 240.2 & - \\
\hline Marchand et al. & 2015 & HT flash & 47 & 5.17 & 41.83 & - \\
\hline Marchand et al. & 2015 & HT flash & 38.5 & 3.85 & 34.65 & - \\
\hline Marchand et al. & 2015 & HT flash & 39.4 & 5.122 & 34.278 & - \\
\hline Martínez-Corona et al. & 2017 & HT flash & 118.35 & - & 117 & - \\
\hline
\end{tabular}




\section{Table A-7. Studies Screened, with Results for Each Screening Criterion}

"Y" (yes) indicates that the source met the requirement, while "N" (no) means it did not pass. A "-" indicates that the criterion was not applicable for that study. A "Y" in column P1 (P2) indicates that the study passed the first (second) screen. The table is sorted first on whether the sources passed the first screen, then whether they passed the second screen, then alphabetically. A description of each screening column is presented in Table A-8.

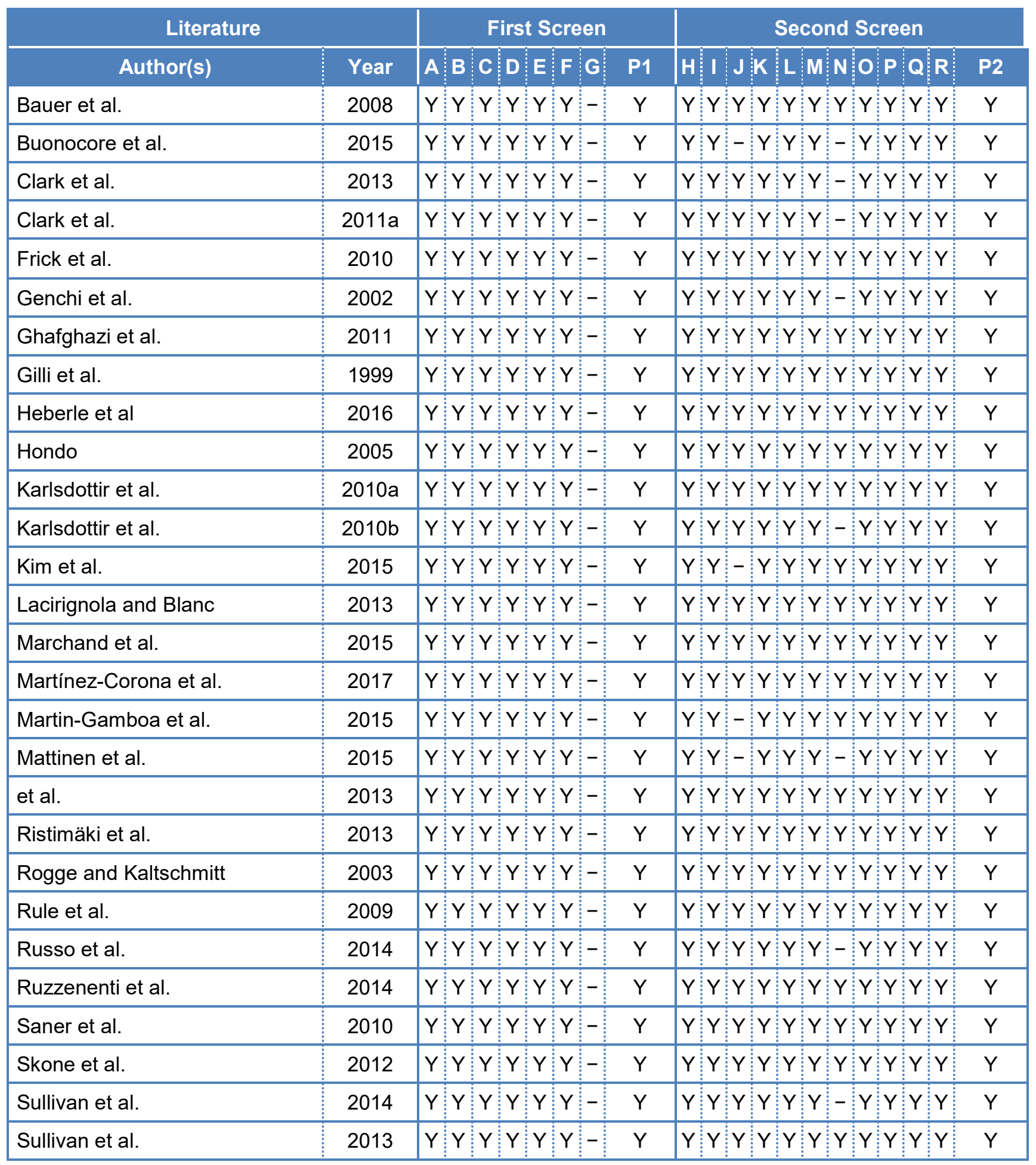




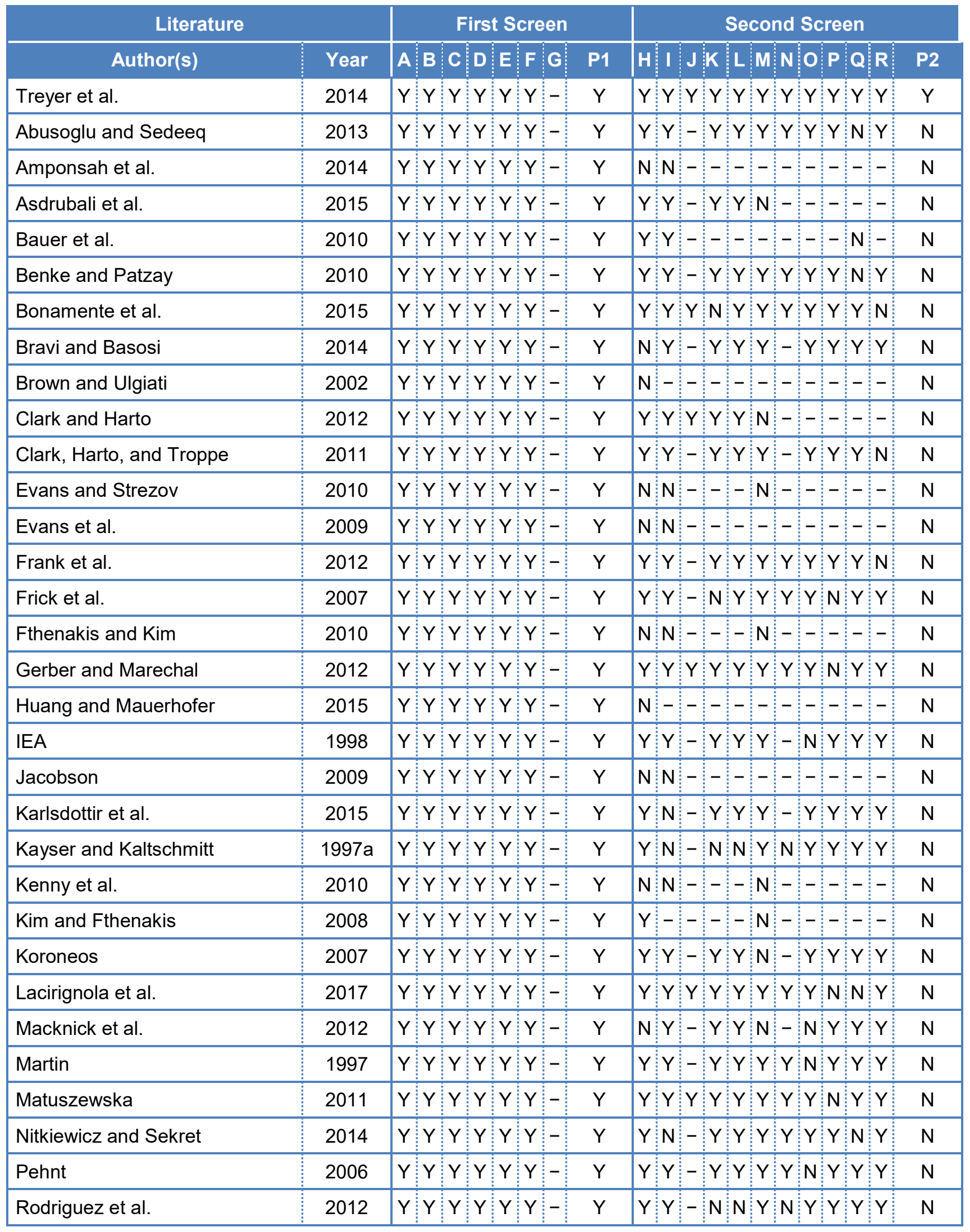




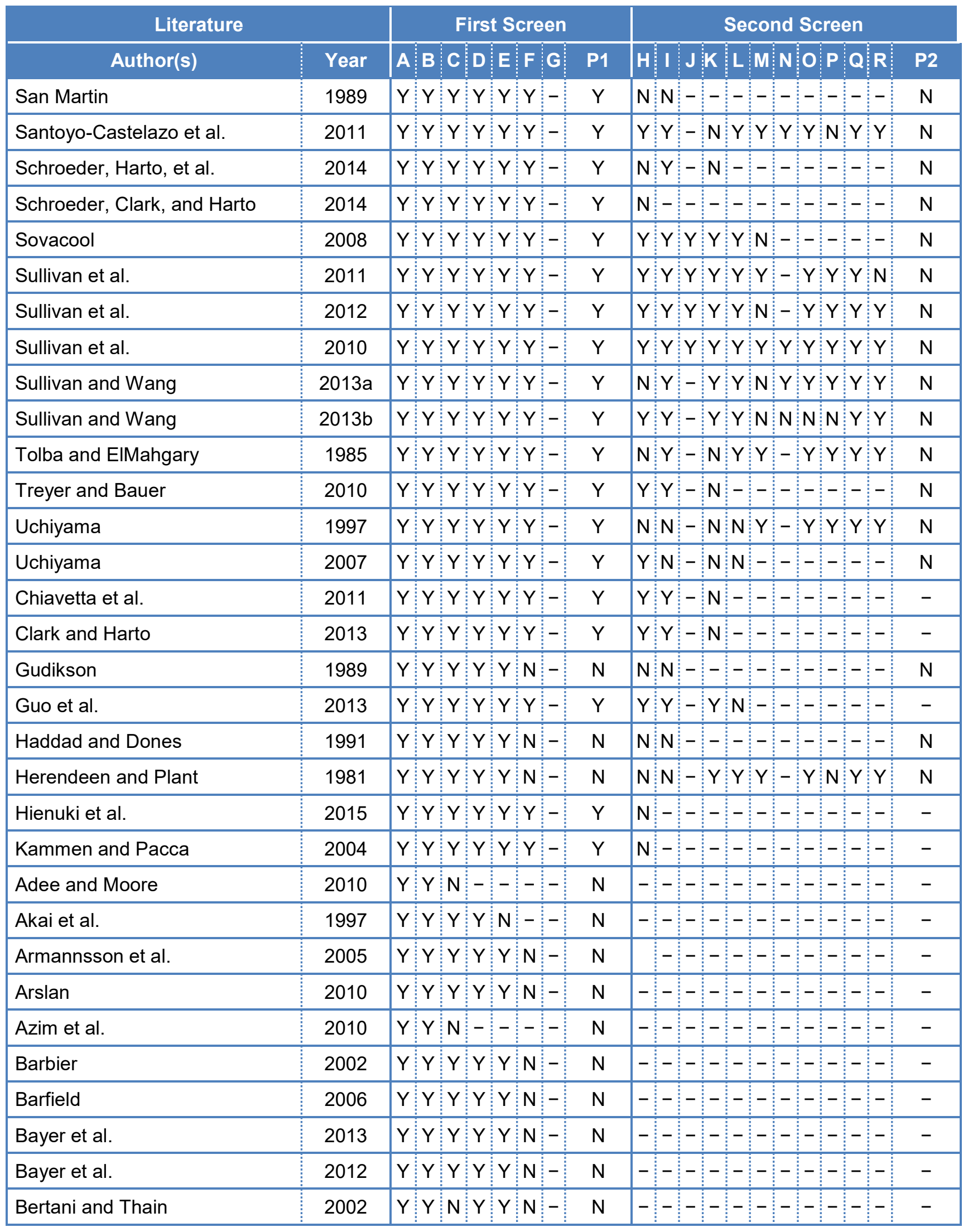




\begin{tabular}{|c|c|c|c|c|c|c|c|c|c|c|c|c|c|c|c|c|c|c|c|c|}
\hline \multicolumn{2}{|l|}{ Literature } & \multicolumn{7}{|c|}{ First Screen } & \multicolumn{12}{|c|}{ Second Screen } \\
\hline Author(s) & Year & A & $B$ & C $\mid \mathbf{D}$ & $\mathbf{E} \mid$ & $F$ & G & P1 & $\mathbf{H} \mid$ & 1 & $\mathbf{J}$ & & & $M \mid r$ & $\mathrm{c}$ & $F$ & C & & $\mathbf{R}$ & P2 \\
\hline Bloomfield and Moore & 1999 & Y & $Y$ & $Y Y$ & $\mathrm{Y}$ & $\mathrm{N}$ & - & $\mathrm{N}$ & & - & - & & - & - & - & - & - & & - & - \\
\hline Bloomfield et al. & 2003 & Y & $Y$ & $\mathrm{~N} \mathrm{Y}$ & Y & $\mathrm{N}$ & - & $\mathrm{N}$ & - & - & - & - & - & - & - & - & 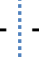 & & - & - \\
\hline Booth and Neil & 1998 & $\mathrm{Y}$ & $Y$ & $\mathrm{~N}-$ & - & - & - & $\mathrm{N}$ & - & - & - & & - & - & - & - & - & . & - & - \\
\hline Boran & 2013 & Y & $Y$ & $Y Y$ & $\mathrm{Y}$ & $\mathrm{N}$ & - & $\mathrm{N}$ & - & - & - & - & - & - & - & - & 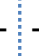 & & - & - \\
\hline Brophy & 1997 & Y & $Y$ & $Y Y$ & $\mathrm{Y}$ & $\mathrm{N}$ & - & $\mathrm{N}$ & - & - & - & - & - & - & - & - & - & & - & - \\
\hline Brugman et al. & 1995 & Y & $Y$ & $Y Y$ & Y & $\mathrm{N}$ & - & $\mathrm{N}$ & - & - & - & - & - & - & - & - & 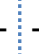 & - & - & - \\
\hline Canelli et al. & 2015 & Y & $Y$ & $Y Y$ & Y & $\mathrm{N}$ & - & $\mathrm{N}$ & - & - & - & - & - & - & - & - & - & & - & - \\
\hline Carvalho et al. & 2015 & Y & $Y$ & $Y Y$ & $Y$ & $\mathrm{~N}$ & - & $\mathrm{N}$ & - & - & - & & - & - & - & - & - & & - & - \\
\hline Chamorro et al. & 2012 & Y & $Y$ & $Y Y$ & Y & $\mathrm{N}$ & - & $\mathrm{N}$ & - & - & - & - & - & - & - & - & 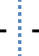 & & - & - \\
\hline Clark et al. & 2009 & $Y$ & $Y$ & $Y Y$ & $Y$ & $\mathrm{~N}$ & - & $\mathrm{N}$ & - & - & - & - & - & - & - & - & - & - & - & - \\
\hline Clark et al. & $2011 b$ & Y & $\mathrm{N}$ & $Y Y$ & Y & $\mathrm{N}$ & - & $\mathrm{N}$ & - & - & - & & 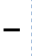 & - & - & 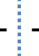 & - & & - & - \\
\hline Clark et al. & 2014 & $Y$ & $Y$ & $Y Y$ & Y & $\mathrm{N}$ & - & $\mathrm{N}$ & - & - & - & & & - & - & - & - & & - & - \\
\hline DiPippo & 1988 & $Y$ & $Y$ & $N-$ & - & - & - & $\mathrm{N}$ & - & - & - & - & 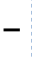 & - & - & - & - & & - & - \\
\hline DiPippo & 2008 & $Y$ & $Y$ & $Y Y$ & $\mathrm{Y}$ & $\mathrm{N}$ & - & $\mathrm{N}$ & & - & - & & - & - & - & - & 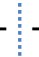 & & - & - \\
\hline Dones et al. & 2007 & $Y$ & $Y$ & $Y Y$ & $N$ & $Y$ & - & $\mathrm{N}$ & & - & - & - & - & - & - & - & - & 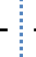 & - & - \\
\hline Dones et al. & 1999 & $Y$ & $\mathrm{~N}$ & $Y Y$ & $\mathrm{~N}$ & - & - & $\mathrm{N}$ & - & - & - & 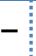 & 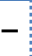 & - & - & 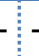 & t & & - & - \\
\hline Dones et al. & 2005 & $Y$ & $Y$ & $Y Y$ & $N$ & - & - & $\mathrm{N}$ & - & - & - & - & - & - & - & - & 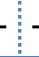 & & - & - \\
\hline Dotzauer & 2010 & $Y$ & $Y$ & $Y Y$ & Y I & $\mathrm{N}$ & - & $\mathrm{N}$ & - & - & - & - & - & - & - & - & - & & - & - \\
\hline Eggertson & 2004 & $Y$ & $Y$ & $N-$ & - & - & - & $\mathrm{N}$ & - & - & - & & & - & - & 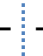 & 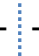 & & - & - \\
\hline Ekrami and Sadeghi & 2009 & Y & $\mathrm{N}$ & Y N & $1-$ & - & - & $\mathrm{N}$ & - & - & - & - & - & - & - & - & - & & - & - \\
\hline El-Emam and Dincer & 2013 & Y & $Y$ & $Y Y$ & Y & $\mathrm{N}$ & - & $\mathrm{N}$ & - & - & - & & - & - & 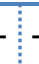 & 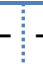 & 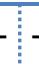 & & - & - \\
\hline Falcone and Borggard & 1991 & $\mathrm{Y}$ & $Y$ & $\mathrm{NY}$ & $\mathrm{Y} 1$ & $\mathrm{~N}$ & - & $\mathrm{N}$ & - & - & - & 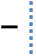 & - & - & - & - & 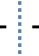 & & - & - \\
\hline Feck and Wagner & 2008 & $\mathrm{Y}$ & $Y$ & $Y N$ & $Y$ & $\mathrm{Y}$ & - & $\mathrm{N}$ & - & - & - & - & - & - & - & - & - & & - & - \\
\hline Frick and Kaltschmitt & 2009 & $\mathrm{Y}$ & $\mathrm{N}$ & Y N & $1-$ & - & - & $\mathrm{N}$ & - & - & - & & & - & - & - & 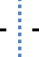 & & - & - \\
\hline Frischknecht et al. & 2009 & $\mathrm{Y}$ & $Y$ & $Y Y$ & $\mathrm{NI}$ & $\mathrm{N}$ & - & $\mathrm{N}$ & - & - & - & - & 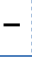 & - & - & - & 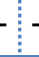 & & - & - \\
\hline Gagnon et al. & 2002 & $\mathrm{Y}$ & $Y$ & Y Y & $\mathrm{N}$ & $Y$ & - & $\mathrm{N}$ & - & - & - & & & - & - & - & - & & - & - \\
\hline Ganjehsarabi et al. & 2012 & Y & $\mathrm{Y}$ & $Y Y$ & $\mathrm{Y} 1$ & $\mathrm{~N}$ & - & $\mathrm{N}$ & - & - & - & & & - & 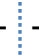 & - & 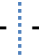 & - & - & - \\
\hline Geothermal Technologies Office & 2008 & Y & $\mathrm{Y}$ & $Y Y$ & $\mathrm{Y} 1$ & $\mathrm{~N}$ & - & $\mathrm{N}$ & - & - & - & - & - & - & 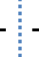 & - & - & & - & - \\
\hline Hadian and Madani & 2015 & $\mathrm{Y}$ & $\mathrm{Y}$ & Y Y & Y & $\mathrm{N}$ & - & $\mathrm{N}$ & & - & - & & & - & 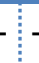 & 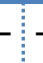 & - & & - & - \\
\hline Hamamatsu & 2003 & $\mathrm{Y}$ & & $Y N$ & $1-$ & - & - & $\mathrm{N}$ & - & - & - & & & - & - & - & - & & - & - \\
\hline Hamamatsu et al. & 2004 & $\mathrm{Y}$ & $\mathrm{Y}$ & Y Y & Y & $\mathrm{N}$ & - & $\mathrm{N}$ & - & - & - & & 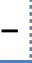 & - & 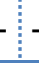 & 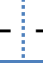 & 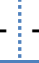 & & - & - \\
\hline Hammons & 2007 & $Y$ & & $Y Y$ & $\mathrm{YI}$ & $\mathrm{N}$ & - & $\mathrm{N}$ & & - & - & & - & - & - & - & 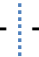 & & - & - \\
\hline
\end{tabular}




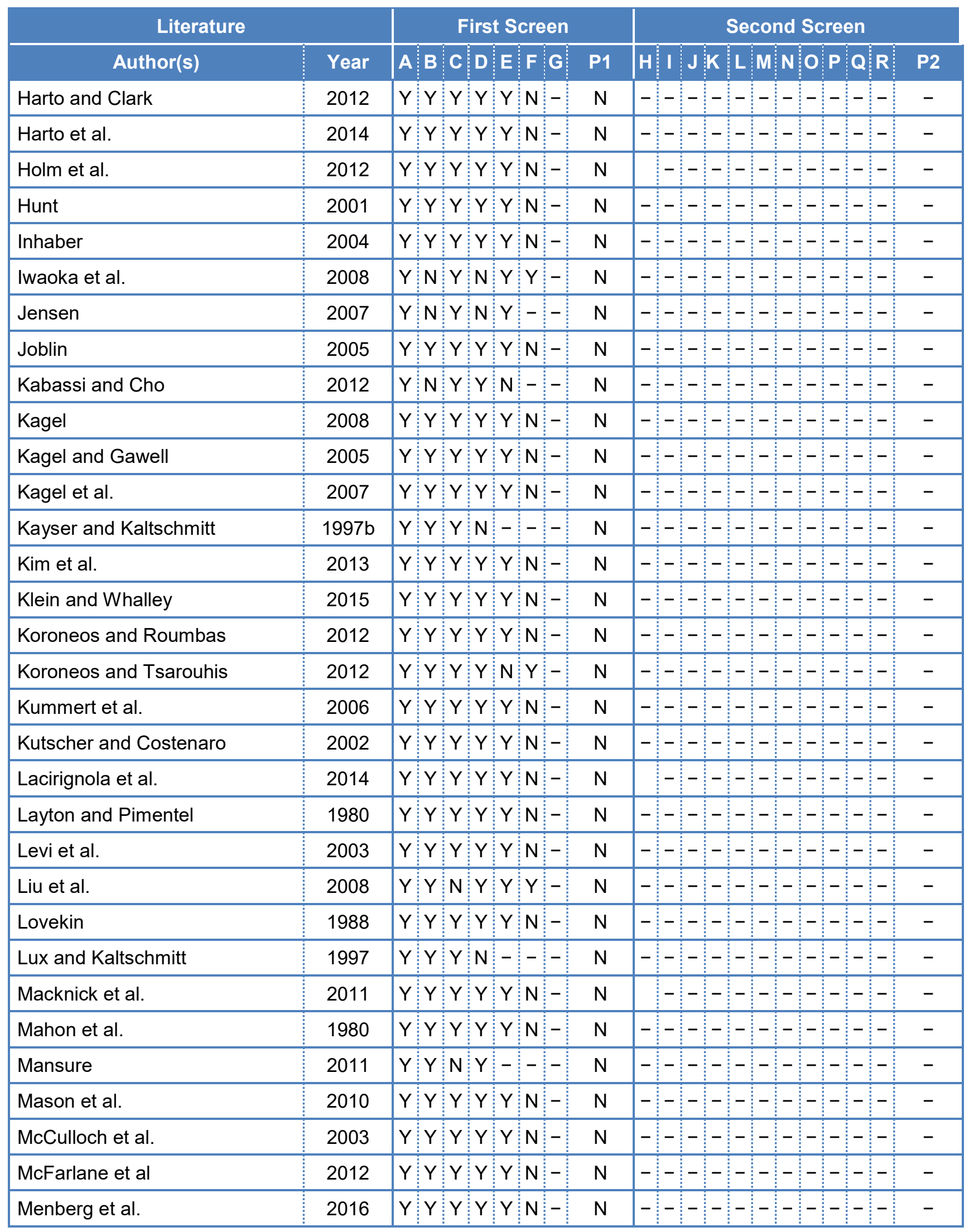




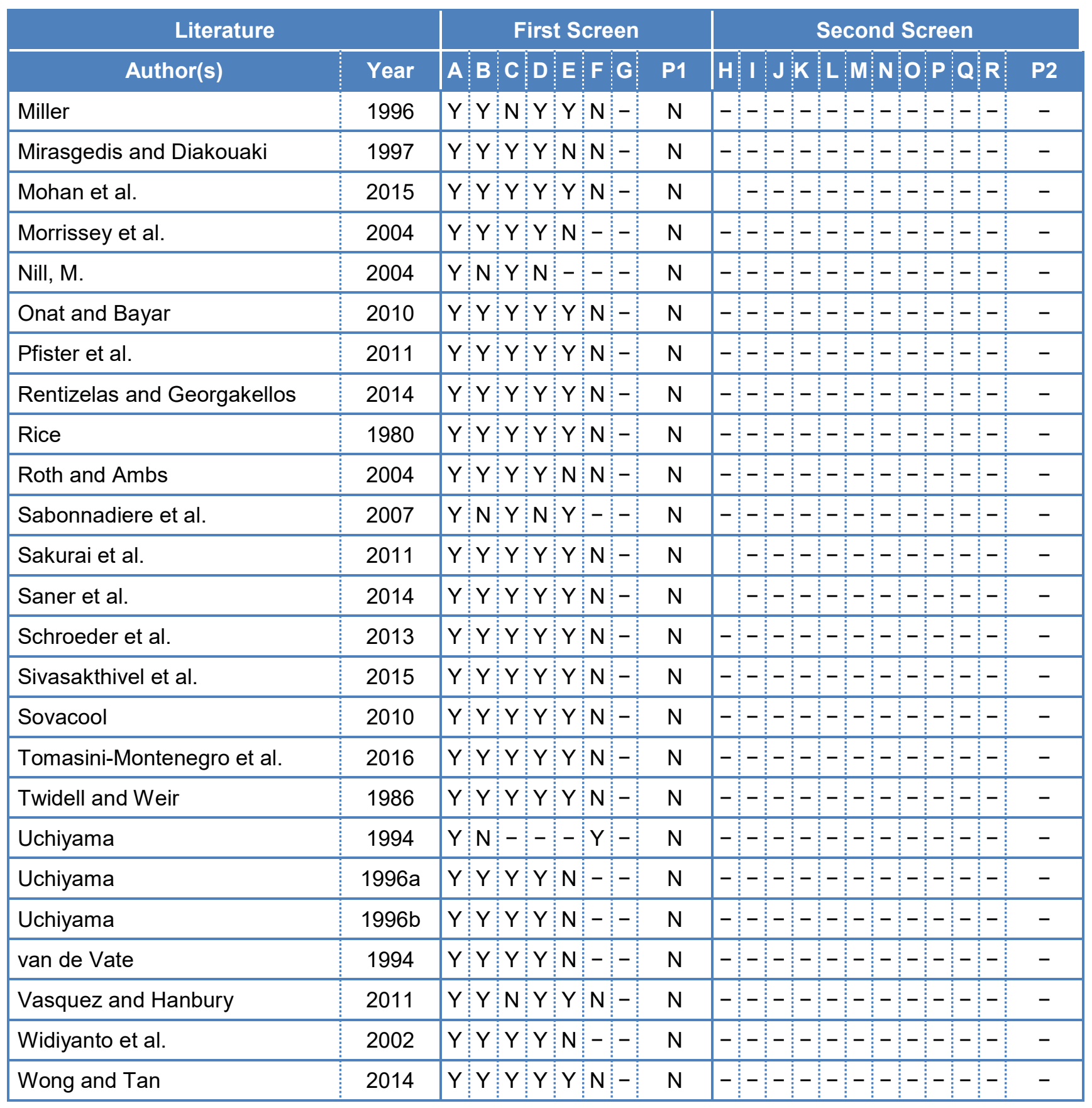


Table A-8. Description of Screening Columns

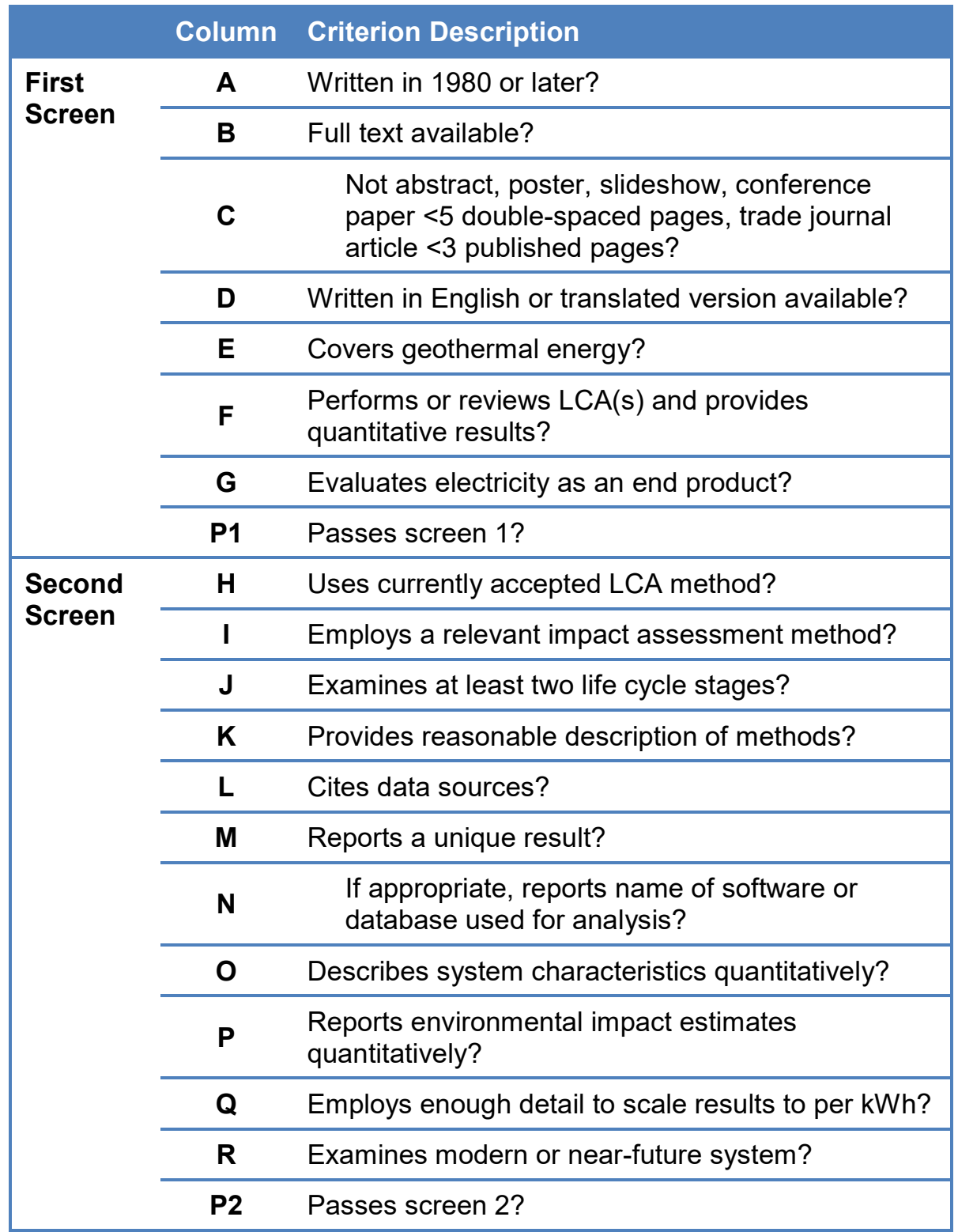




\section{References for Table A-7}

Abusoglu, A., and M.S. Sedeeq. 2013. "Comparative Exergoenvironmental Analysis and Assessment of Various Residential Heating Systems." Energy and Buildings 62: 268-77. doi:10.1016/j.enbuild.2013.03.024.

Adee, S., and S. Moore. 2010. “The Power of Water.” IEEE Spectrum 47 (6): 30-39.

Akai, M., N. Nomura, H. Waku, and M. Inoue. 1997. "Life-Cycle Analysis of a Fossil-Fuel Power Plant with CO2 Recovery and a Sequestering System." Energy 22, no. 2-3 (1997): 249255.

Amponsah, Nana Yaw, Mads Troldborg, Bethany Kington, Inge Aalders, and Rupert Lloyd Hough. 2014. "Greenhouse Gas Emissions from Renewable Energy Sources: A Review of Lifecycle Considerations." Renewable \& Sustainable Energy Reviews 39 (November): 461-75. doi:10.1016/j.rser.2014.07.087.

Armannsson, Halldor, Thrainn Fridriksson, and Bjarni Reyr Kristjansson. 2005. "CO 2 Emissions from Geothermal Power Plants and Natural Geothermal Activity in Iceland." Geothermics, no. 34.3: 286-96.

Arslan, Oguz. 2010. "Exergoeconomic Evaluation of Electricity Generation by the Medium Temperature Geothermal Resources, Using a Kalina Cycle: Simav Case Study." International Journal of Thermal Sciences 49 (2010). doi:10.1016/j.ijthermalsci.2010.05.009.

Asdrubali, Francesco, Giorgio Baldinelli, Francesco D’Alessandro, and Flavio Scrucca. 2015. "Life Cycle Assessment of Electricity Production from Renewable Energies: Review and Results Harmonization." Renewable \& Sustainable Energy Reviews 42 (February): 1113-22. doi:10.1016/j.rser.2014.10.082.

Azim, M.R., M.S. Amin, and M.A. Shoeb. 2010. "Prospect of Enhanced Geothermal System in Baseload Power Generation." In 2010 IEEE International Conference on Advanced Management Science (ICAMS), 3:176-80. doi:10.1109/ICAMS.2010.5553262.

Barbier, E. 2002. "Geothermal Energy Technology and Current Status: An Overview." Renewable \& Sustainable Energy Reviews, no. 6: 3-65.

Barfield, Al. 2006. "Hybrid Geothermal Heat Pumps for Beachfront Hotel." ASHRAE Journal 48 (9): $48-52+55$.

Bauer, C., R. Dones, T. Heck, and S. Hirschberg. 2008. "Environmental Assessment of Current and Future Swiss Electricity Supply Options." In International Conference on Reactor Physics, Nuclear Power: A Sustainable Resource, September 14-19, 2008, Interlaken, Switzerland.

Bauer, C., W. Schenler, and S. Roth. 2010. "A Comparative Sustainability Assessment of Combined Heat and Electricity Supply by Cogeneration and Heat Pump Systems for Switzerland." In ECOS 2010, June 14-17, 2010, Lausanne, Switzerland. 1:357-64. 
Bayer, Peter, Ladislaus Rybach, Philipp Blum, and Ralf Brauchler. 2013. "Review on Life Cycle Environmental Effects of Geothermal Power Generation." Renewable \& Sustainable Energy Reviews 26 (October): 446-63. doi:10.1016/j.rser.2013.05.039.

Bayer, Peter, Dominik Saner, Stephan Bolay, Ladislaus Rybach, and Philipp Blum. 2012. "Greenhouse Gas Emission Savings of Ground Source Heat Pump Systems in Europe: A Review." Renewable \& Sustainable Energy Reviews 16 (2): 1256-67. doi:10.1016/j.rser.2011.09.027.

Benke, Boglarka, and Gyoergy Patzay. 2010. "The Environmental Evaluation of Utilising Geothermal Energy with the Life-Cycle Method." Periodica Polytechnica-Chemical Engineering 54 (2): 63-69. doi:10.3311/pp.ch.2010-2.02.

Bertani, R, and I Thain. 2002. "Geothermal Power Generating Plant CO2 Emission Survey." IGA News 49: 1-3.

Bloomfield, K. K., and J. N. Moore. 1999. "Production of Greenhouse Gases from Geothermal Power Plants." Geothermal Resource Council Transactions, no. 23: 221-23.

Bloomfield, K. K., J. N. Moore, and Neilson. 2003. "Geothermal Energy Reduces Greenhouse Gas Emissions.” Geothermal Resource Council Transactions, 77-79.

Bonamente, E., L. Pelliccia, M.C. Merico, S. Rinaldi, and A. Petrozzi. 2015. "The Multifunctional Environmental Energy Tower: Carbon Footprint and Land Use Analysis of an Integrated Renewable Energy Plant.”S Sustainability (Switzerland) 7 (10): 13564-84. doi:10.3390/su71013564.

Booth, R. B., and P. E. Neil. 1998. "An Expanded Review and Comparison of Greenhouse Gas Emissions from Fossil Fuel and Geothermal Electrical Generating Facilities." In Air \& Waste Management Association 91st Annual Meeting \& Exhibition, San Diego, California, June 14-18, 1998. http:/www.osti.gov/scitech/biblio/679364-expanded-review-comparison-greenhouse-gasemissions-from-fossil-fuel-geothermal-electrical-generating-facilities.

Boran, F.E. 2013. "A Multidimensional Analysis to Evaluate District Heating Systems.” Energy Sources, Part B: Economics, Planning and Policy 8 (2): 122-29. doi:10.1080/15567240903289556.

Bravi, Mirko, and Riccardo Basosi. 2014. "Environmental Impact of Electricity from Selected Geothermal Power Plants in Italy." Journal of Cleaner Production 66 (March): 301-8. doi:10.1016/j.jclepro.2013.11.015.

Brophy, P. 1997. "Environmental Advantages to the Utilization of Geothermal Energy." Renewable Energy 10 (2-3 SPEC. ISS.): 367-77.

Brown, M.T., and S. Ulgiati. 2002. "Emergy Evaluations and Environmental Loading of Electricity Production Systems.” Journal of Cleaner Production, no. 10: 321-34. 
Brugman, John, Mai Hattar, Kenneth Nichols, and Yuri Esaki. 1995. "Next Generation Geothermal Power Plants.” EPRI-95-02; EPRI RP 3657-01. CE Holt Company, Pasadena, California. http://www.osti.gov/scitech/biblio/894305-next-generation-geothermal-power-plants.

Buonocore, Elvira, Laura Vanoli, Alberto Carotenuto, and Sergio Ulgiati. 2015. "Integrating Life Cycle Assessment and Emergy Synthesis for the Evaluation of a Dry Steam Geothermal Power Plant in Italy." Energy 86 (June): 476-87. doi:10.1016/j.energy.2015.04.048.

Canelli, M., E. Entchev, M. Sasso, L. Yang, and M. Ghorab. 2015. "Dynamic Simulations of Hybrid Energy Systems in Load Sharing Application.” Applied Thermal Engineering 78: 31525. doi:10.1016/j.applthermaleng.2014.12.061.

Carvalho, Anabela Duarte, Dimitris Mendrinos, and Anibal T. De Almeida. 2015. "Ground Source Heat Pump Carbon Emissions and Primary Energy Reduction Potential for Heating in Buildings in Europe-Results of a Case Study in Portugal." Renewable \& Sustainable Energy Reviews 45 (May): 755-68. doi:10.1016/j.rser.2015.02.034.

Chamorro, C.R., M.E. Mondéjar, R. Ramos, J.J. Segovia, M.C. Martín, and M.A. Villamañán. 2012. "World Geothermal Power Production Status: Energy, Environmental and Economic Study of High Enthalpy Technologies." Energy 42 (1): 10-18. doi:10.1016/j.energy.2011.06.005.

Chiavetta, C., F. Tinti, and A. Bonolia. 2011. "Comparative Life Cycle Assessment of Renewable Energy Systems for Heating and Cooling." Procedia Engineering 21 (2011), pp. 591597. doi:10.1016/j.proeng.2011.11.2054.

Clark, C., and C. Harto. 2012. "Water Use in Geopressured Geothermal Systems." GRC Transactions 362 (2012):1187-90. http://www.scopus.com/inward/record.url?eid=2-s2.084876249494\&partnerID=40\&md5=99ed9afce9f021c5f754e25832d0bc35.

- 2013. "Lifecycle Water Consumption of Geothermal Power Systems." In ASME Power Conference Vol 2, July 29-August 1, 2013, Boston, Massachusetts. doi:10.1115/POWER201398167.

Clark, C., C. Harto, J. Sullivan, and M. Wang. 2011a. "Water Use in the Development and Operation of Geothermal Power Plants." ANL/EVS/R-10/5. Argonne National Laboratory.

Clark, C., C. Harto, J. Sullivan, and M. Wang. 2011b. "Water Use and Geothermal Power Plants." GRC Transactions 35, no. 1 (2011):593-96. http://www.scopus.com/inward/record.url?eid=2-s2.084860845584\&partnerID=40\&md5=6d4c383be2ef22805f02e03455aa3c99.

Clark, C., M. Wang, A. Vyas, and J. Gasper. 2009. "Life Cycle Approach to Understanding Impacts of EGS.” GRC Transactions 33 (2009):280-83.

http://www.scopus.com/inward/record.url?eid=2-s2.077952618564\&partnerID=40\&md5=a522dbaf25969538431a3f8e4ee 12014 . 
Clark, C.E., C.B. Harto, and W.A. Troppe. 2011. "Water Resource Assessment of Geothermal Resources and Water Use in Geopressured Geothermal Systems.” ANL/EVS/R-11/10. Environmental Science Division, Argonne National Laboratory.

Clark, C.E., J.N. Schroeder, A. Anderson, and C.B. Harto. 2014. "Consumption of Water in Geothermal Development, NEPA, and the National Geothermal Data System." GRC Transactions 38 (2014):839-45.

Clark, Corrie E., Christopher B. Harto, Jenna N. Schroeder, Louis E. Martino, and Robert M. Horner. 2013. "Life Cycle Water Consumption and Water Resource Assessment for Utility-Scale Geothermal Systems: An in-Depth Analysis of Historical and Forthcoming Egs Projects." ANL/EVS/R-12/8. Argonne National Laboratory (ANL), Argonne, IL (United States). http://www.osti.gov/scitech/biblio/1117360-life-cycle-water-consumption-water-resourceassessment-utility-scale-geothermal-systems-depth-analysis-historical-forthcoming-egs-projects.

DiPippo, R. 2008. Geothermal Power Plants: Principles, Applications, Case Studies and Environmental Impact. Burlington, MA: Butterworth-Heinemann (Elsevier).

DiPippo, R. (Southeastern Massachusetts Univ. 1988. "Geothermal Energy and the Greenhouse Effect." Geothermal Hot Line; (USA) 18:2 (December). http:/www.osti.gov/scitech/biblio/7158617-geothermal-energy-greenhouse-effect.

Dones, R., C. Bauer, B. Bolliger, Bastian Burger, T. Heck, Roder.Alexander, Mireille Faist Emmenegger, Rolf Frischknecht, Niels Jungbluth, and Matthias Tuchschmid. 2007. "Life Cycle Inventories of Energy Systems: Results for Current Systems in Switzerland and Other UCTE Countries." EcoInvent Data v2.0.

Dones, R., U. Ganter, and S. Hirschberg. 1999. "Environmental Inventories for Future Electricity Supply Systems for Switzerland.” International Journal of Global Energy Issues 12 (1): 271-82.

Dones, R., T. Heck, C. Bauer, Stefan Hirschberg, Peter Bickel, Philipp Preiss, Luc Int Panis, and Ina De Vlieger. 2005. "Externalities of Energy: Extension of Accounting Framework and Policy Applications." ExternE-Pol.

Dotzauer, E. 2010. "Greenhouse Gas Emissions from Power Generation and Consumption in a Nordic Perspective.” Energy Policy 38 (2): 701-4. doi:10.1016/j.enpol.2009.10.066.

Eggertson, Bill. 2004. "Green Heat The Unsung Hero of Renewable.” reFocus.

Ekrami, A., and M. Sadeghi. 2009. "Evaluation of geothermal power plants development: An environmental economics perspective." Journal of Environmental Studies 35 (49): 83-88.

El-Emam, R.S., and I. Dincer. 2013. "Exergy and Exergoeconomic Analyses and Optimization of Geothermal Organic Rankine Cycle." Applied Thermal Engineering 59 (1-2): 435-44. doi:10.1016/j.applthermaleng.2013.06.005. 
Evans, Annette, and Vladimir Strezov. 2010. "A Sustainability Assessment of Electricity Generation.” In 2010 International Conference on Biosciences, Cancún, Mexico, March 7-13, 2010. doi:10.1109/BioSciencesWorld.2010.29.

Evans, Annette, Vladimir Strezov, and Tim J. Evans. 2009. “Assessment of Sustainability Indicators for Renewable Energy Technologies." Renewable \& Sustainable Energy Reviews 13 (5): 1082-88. doi:10.1016/j.rser.2008.03.008.

Falcone, Domenic, and Eric Borggard. 1991. "Competitive Pricing of Geothermal Energy, Including Externalities.” GRC Transactions 15 (1991):95-97.

Feck, Norbert, and Hermann-Josef Wagner. 2008. "Lifecycle assesment by Monte-Carlosimulation. Analyses at the example of a heatplan, based on the hot-dry-rock technology; Lebenszyklusanalyse mittels Monte-Carlo-Simulation. Untersuchung am Beispiel eines Hot-DryRock-Heizwerkes.” BWK. Das Energie-Fachmagazin 60 (9): 52-58.

Frank, Edward D., John L. Sullivan, and Michael Q. Wang. 2012. "Life Cycle Analysis of Geothermal Power Generation with Supercritical Carbon Dioxide." Environmental Research Letters 7 (3): 34030. doi:10.1088/1748-9326/7/3/034030.

Frick, S., and M. Kaltschmitt. 2009. "Environmental Aspects of Geothermal Power Generation Analysis and Evaluation of Environmental Impacts in the Life Cycle." Erdoel Erdgas Kohle 125 (1): $37-42$.

Frick, S., M. Kaltschmitt, and G. Schroder. 2010. "Life Cycle Assessment of Geothermal Binary Power Plants Using Enhanced Low-Temperature Reservoirs.” Energy 35 (5): 2281-94. doi:10.1016/j.energy.2010.02.016.

Frick, S., C Lohse, and M. Kaltschmitt. 2007. "Environmental Impacts through Geothermal Power Generation in Germany.” ENGINE Workshop 6, Athens, September.

Frischknecht, R., S. Büsser, and W. Krewitt. 2009. "Environmental Assessment of Future Technologies: How to Trim LCA to Fit This Goal?" International Journal of Life Cycle Assessment 14 (6): 584-88. doi:10.1007/s11367-009-0120-6.

Fthenakis, Vasilis, and Hyung Chul Kim. 2010. "Life-Cycle Uses of Water in U.S. Electricity Generation." Renewable and Sustainable Energy Reviews In Press, Uncorrected Proof. doi:10.1016/j.rser.2010.03.008.

Gagnon, L., C. Belanger, and Y. Uchiyama, Y. 2002. "Lifecycle Assessment of Electricity Generation Options: The Status of Research in Year 2001.” Energy Policy, no. 30: 1267-78.

Ganjehsarabi, H., A. Gungor, and I. Dincer. 2012. "Exergetic Performance Analysis of Dora II Geothermal Power Plant in Turkey.” Energy 46 (1): 101-8. doi:10.1016/j.energy.2012.02.039. 
Genchi, Yutaka, Yukihiro Kikegawa, and Atsushi Inaba. 2002. "CO2 Payback-Time Assessment of a Regional-Scale Heating and Cooling System Using a Ground Source Heat-Pump in a High Energy-Consumption Area in Tokyo.” Applied Energy 71 (3): 147-60. doi:10.1016/S03062619(02)00010-7.

Geothermal Technologies Program. 2008. "An Evaluation of Enhanced Geothermal Systems Technology.” U.S. Department of Energy, Energy Efficiency and Renewable Energy: Geothermal Technologies Office. http://www1.eere.energy.gov/geothermal/pdfs/evaluation_egs_tech_2008.pdf.

Gerber, Leda, and Francois Marechal. 2012. "Environomic Optimal Configurations of Geothermal Energy Conversion Systems: Application to the Future Construction of Enhanced Geothermal Systems in Switzerland.” Energy 45 (1): 908-23. doi:10.1016/j.energy.2012.06.068.

Ghafghazi, Saeed, Taraneh Sowlati, Shahab Sokhansanj, Xiaotao Bi, and Staffan Melin. 2011. "Life Cycle Assessment of Base-load Heat Sources for District Heating System Options." The International Journal of Life Cycle Assessment 16 (3): 212-23. doi:10.1007/s11367-011-0259-9.

Gilli, P.V., W. Streicher, H. Halozan, and G. Beembroek. 1999. "Environmental Benefits of Heat Pumping Technologies." HPC-AR--6. ARGE Waermetechnik, Graz, Austria EA Heat Pump Centre, Sittard, Netherlands. ETDE.

Gudikson, P.H. 1989. "Field Studies For Determining The Characteristics And Dynamics Of Local Circulations.” Argonne National Lab., IL.

Guo, M.J., J. Ding, and Y.F. Liu. 2013. "A Life-Cycle Assessment of Geothermal Heating Project with Low-Temperature Reservoirs in China." Advanced Materials Research 807-809: 294-300. doi:10.4028/www.scientific.net/AMR.807-809.294

Haddad, S., and R. Dones. 1991. "Comparative Health and Environmental Risks for Various Energy Sources.” IAEA Bulletin. International Atomic Energy Agency.

Hadian, S., and K. Madani. 2015. "A System of Systems Approach to Energy Sustainability Assessment: Are All Renewables Really Green?” Ecological Indicators 52: 194-206. doi:10.1016/j.ecolind.2014.11.029.

Hamamatsu. 2003. "Effective Energy Conservation and Reduction of Carbon Dioxide Emissions from the Viewpoint Of “energy Chain.”' Japan Institute of Energy 82, no. 10 (2003): 793-796.

Hamamatsu, T., M. Saikawa, and K. Hashimoyo. 2004. "Energy Chain-A new concept in evaluating future energy conservation and greenhouse abatement alternatives and effectiveness." In 19th World Energy Congress. Sydney, Australia.

Hammons, T.J. 2007. "Geothermal Power Generation: Global Perspectives; U.S.A. and Iceland; Technology, Direct Uses, Plants, and Drilling." International Journal of Power and Energy Systems 27 (2): 157-72. 
Harto, C., and C. Clark. 2012. "Geothermal Regional Water Resource Assessment." GRC Transactions 36, no. 2 (2012):1203-8. http://www.scopus.com/inward/record.url?eid=2-s2.084876254648\&partnerID=40\&md5=51 eda0fee2b538cd76cf37b9adb2eeb5.

Harto, C.B., J.N. Schroeder, R.M. Horner, T.L. Patton, L.A. Durham, D.J. Murphy, and C.E. Clark. 2014. "Water Use in Enhanced Geothermal Systems (EGS): Geology of U.S. Stimulation Projects, Water Costs, and Alternative Water Use Policies." 464. DOE Geothermal Data Repository; Argonne National Laboratory. http://www.osti.gov/scitech/biblio/1170247-wateruse-enhanced-geothermal-systems-egs-geology-stimulation-projects-water-costs-alternativewater-use-policies.

Heberle, Florian, Christopher Schifflechner, and Dieter Brüggemann. 2016. "Life Cycle Assessment of Organic Rankine Cycles for Geothermal Power Generation Considering LowGWP Working Fluids." Geothermics 64 (November): 392-400.

doi:10.1016/j.geothermics.2016.06.010.

Herendeen, R.A., and R.I. Plant. 1981. "Energy Analysis of Four Geothermal Technologies." Energy 6 (1): 73-82.

Hienuki, Shunichi, Yuki Kudoh, and Hiroki Hondo. 2015. "Life Cycle Employment Effect of Geothermal Power Generation Using an Extended Input-output Model: The Case of Japan." Journal of Cleaner Production 93 (April): 203-12. doi:10.1016/j.jclepro.2015.01.008.

Holm, Alison, Dan Jennejohn, and Leslie Blodgett. 2012. "Geothermal Energy Reduces Greenhouse Gas Emissions.” Geothermal Energy Association.

Hondo, Hiroki. 2005. "Life Cycle GHG Emission Analysis of Power Generation Systems: Japanese Case.” Energy 30 (11-12 SPEC ISS): 2042-56.

Huang, B., and V. Mauerhofer. 2015. "Life Cycle Sustainability Assessment of Ground Source Heat Pump inShanghai, China." Scopus. http://www.scopus.com/inward/record.url?eid=2-s2.084941248442\&partnerID=40\&md5=f015038ee2eec8530f7292be099d91be.

Hunt, T.M. 2001. "Five Lectures on Environmental Effects of Geothermal Utilization." Reykjavik, Iceland: United Nations University, Geothermal Training Programme.

IEA. 1998. "The Environmental Implications of Renewables. Interim Report [Later Published as Benign Energy].” Paris: International Energy Agency. http://www.iea.org/textbase/nppdf/free/1990/benign1998.pdf.

Inhaber, H. 2004. "Water Use in Renewable and Conventional Electricity Production." Energy Sources 26 (3): 309-22.

Iwaoka, S., H. Yamazaki, and T. Watanabe. 2008. "Life Cycle Assessment of the Energy Conservation House That Uses Geothermal." Journal of Environmental Engineering 73 (625): 401-8. doi:10.3130/aije.73.401. 
Jacobson, Mark Z. 2009. "Review of Solutions to Global Warming, Air Pollution, and Energy Security." Energy \& Environmental Science 2: 148-73. doi:10.1039/b809990C.

Jensen, Dierk. 2007. “Energy from below; Energieernte unterm Rasen.” Neue Energie 117 (2): $40-42$.

Joblin, Nathan. 2005. "Geothermal Heat Pumps: Environmental and Economic Benefits for Public Buildings.” University of San Francisco.

Kabassi, K., and Y.K. Cho. 2012. "BLCC Analysis Derived from BIM and Energy Data of Zero Net Energy Test Home." In International Conference on Sustainable Design and Construction (ICSDC) 2011, Kansas, City, Missouri, March 23-25, 2011. doi:10.1061/41204(426)37.

Kagel, A., and K. Gawell. 2005. "Promoting Geothermal Energy: Air Emissions Comparison and Externality Analysis.” Electricity Journal 18 (7): 90-99. doi:10.1016/j.tej.2005.07.004.

Kagel, Alyssa. 2008. "The State of Geothermal Technology Part II Surface Technology.” Geothermal Energy Association. http://www.geoenergy.org/reports/Geothermal\%20Technology\%20-\%20Part\%20II\%20(Surface).pdf.

Kagel, Alyssa, Diana Bates, and Karl Gawell. 2007. "A Guide to Geothermal Energy and the Environment." Geothermal Energy Association.

Kammen, D.M., and S. Pacca. 2004. Assessing the Costs of Electricity. Vol. 29. Annual Review of Environment and Resources.

Karlsdottir, M. R., O. P. Palsson, and H. Palsson. 2010a. "Factors for Primary Energy Efficiency and CO2 Emission of Geothermal Power Production." In World Geothermal Congress 2010, Bali, Indonesia, April 25-30, 2010.

_ 2010b. "LCA of Combined Heat and Power Production at Hellisheidi Geothermal Power Plant with Focus on Primary Energy Efficiency." 12th International Symposium on District Heating and Cooling, September 5-7, 2010, Tallinn, Estonia. pp. 184-92.

http://www.scopus.com/inward/record.url?eid=2-s2.079952655547\&partnerID=40\&md5=c9dcdc94bc943f0568faf8a2addf9aee.

Karlsdottir, M. R., O. P. Palsson, H. Palsson, and L. Maya-Drysdale. 2015. "Life Cycle Inventory of a Flash Geothermal Combined Heat and Power Plant Located in Iceland." International Journal of Life Cycle Assessment 20 (4): 503-19. doi:10.1007/s11367-014-0842-y.

Kayser, M., and M. Kaltschmitt. 1997a. "Energy from Hydrothermal Resources - Energy and Environmental Analysis Nutzung Hydrothermaler Erdwaermevorkommen - Energie- Und Umweltanalyse." Erdoel Erdgas Kohle/EKEP 113 (1): 38-41.

1997b. "Nutzung hydrothermaler Erdwaermevorkommen - Energie und Umweltanalyse." In Fachtagung der Schweizerischen Vereinigung fuer Geothermie (SVG): Geothermie - Energie der Zukunft, Konstanz, Germany, Sep 18-20,1996. pp. 356-64. https:/www.etde.org/etdeweb/servlets/purl/573631-KHIkw0/webviewable/573631.pdf. 
Kenny, R., C. Law, and J. M. Pearce. 2010. "Towards Real Energy Economics: Energy Policy Driven by Life-Cycle Carbon Emission.” Energy Policy 38 (4): 1969-78.

doi:10.1016/j.enpol.2009.11.078.

Kim, Chul Hyung, and Vasilis Fthenakis. 2008. "The Fuel Cycles of Electricity Generation: A Comparison of Land Use.” In MRS Online Proceedings Library Archive 1041 (2007):165-71. doi:10.1557/PROC-1041-R05-03

Kim, Heetae, Claudio Tenreiro, and Tae Kyu Ahn. 2013. "2D Representation of Life Cycle Greenhouse Gas Emission and Life Cycle Cost of Energy Conversion for Various Energy Resources." Korean Journal of Chemical Engineering 30 (10): 1882-88. doi:10.1007/s11814013-0121-9.

Kim, J., T. Hong, M. Chae, C. Koo, and J. Jeong. 2015. “An Environmental and Economic Assessment for Selecting the Optimal Ground Heat Exchanger by Considering the Entering Water Temperature.” Energies 8 (8): 7752-76. doi:10.3390/en8087752.

Klein, Sharon J. W., and Stephanie Whalley. 2015. "Comparing the Sustainability of US Electricity Options through Multi-Criteria Decision Analysis.” Energy Policy 79 (April): 12749. doi:10.1016/j.enpol.2015.01.007.

Koroneos, C., and G. Roumbas. 2012. "Geothermal Waters Heat Integration for the Desalination of Sea Water." Desalination and Water Treatment 37 (1-3): 69-76. doi:10/5004/dwt.2012.2271.

Koroneos, C., and M. Tsarouhis. 2012. "Exergy Analysis and Life Cycle Assessment of Solar Heating and Cooling Systems in the Building Environment." Journal of Cleaner Production 32: 52-60. doi:10.1016/j.jclepro.2012.03.012.

Koroneos, Christopher J. 2007. "Renewable Energy Systems: The Environmental Impact Approach.” International Journal of Global Energy Issues 27 (4): 425-41.

Kummert, M., M. Bernier, and M. Roy. 2006. "Using Simulation to Validate and Optimize the Design of a Hybrid Solar-GCHP System." In Proceedings of IBPSA-Canada's 4th Biennial Building Performance Simulation Conference (eSim 2006), Toronto, ON (Canada), May 3-5, 2006.

Kutscher, C., and D. Costenaro. 2002. "Assessment of Evaporative Cooling Enhancement Methods for Air-Cooled Geothermal Power Plants." In Geothermal Resources Council.

Lacirignola, M., B.H. Meany, P. Padey, and I. Blanc. 2014. "A Simplified Model for the Estimation of Life-Cycle Greenhouse Gas Emissions of Enhanced Geothermal Systems." Geothermal Energy 2 (1). doi:10.1186/s40517-014-0008-y.

Lacirignola, Martino, and Isabelle Blanc. 2013. "Environmental Analysis of Practical Design Options for Enhanced Geothermal Systems (EGS) through Life-Cycle Assessment." Renewable Energy 50 (February): 901-14. doi:10.1016/j.renene.2012.08.005. 
Lacirignola, Martino, Philippe Blanc, Robin Girard, Paula Pérez-López, and Isabelle Blanc. 2017. "LCA of Emerging Technologies: Addressing High Uncertainty on Inputs' Variability When Performing Global Sensitivity Analysis." Science of The Total Environment 578 (February): 268-80. doi:10.1016/j.scitotenv.2016.10.066.

Layton, David W., and Kenneth D. Pimentel. 1980. "Geothermal Power Production: Impact Assessments and Environmental Monitoring." In Proceedings of the 26th Annual Technical

Meeting, Institute for Environmental Sciences, Philadelphia, Pennsylvania, May 11-14, 1980.

Levi, Tana P., Keith A. Lichti, Jonathan D. Morris, and David M. Firth. 2003. "Life Cycle Issues of Power Plant in Australia and New Zealand." Materials at High Temperatures 20 (1): 85-92.

Liu, F., J.-J. Cai, and W.-C. Liu. 2008. "Study of Environmental Benefit Ground-Source Heat Pump System with LCA." In Proceedings of the 2008 Global Symposium on Recycling, Waste Treatment and Clean Technology, REWAS 2008, Cancún, Mexico, October 12-15, 2008. 16973. http://www.scopus.com/inward/record.url?eid=2-s2.062549141080\&partnerID $=40 \& \mathrm{md} 5=383 \mathrm{abd} 669 \mathrm{fc} 9 \mathrm{~d} 4915 \mathrm{~cd} 4455950 \mathrm{~d} 00060$.

Lovekin, J. W. 1988. "Sustainable Geothermal Power: The Life Cycle of a Geothermal Field." Transactions - Geothermal Resources Council 22 (September): 515-20.

Lux, R., and M. Kaltschmitt. 1997. "Energy-economic analysis of systems harnessing nearsurface underground geothermal energy; Energiewirtschaftliche Analyse von Anlagen zur Nutzung oberflaechennaher Erdwaerme." In 3rd Symposium on Ground-source Heat Pumps: Systems for Heating and Cooling; Symposium Erdgekoppelte Waermepumpen: Systeme zum Heizen und Kuehlen, November 20-22, 1997 , edited by B. Sanner and A. Lehmann, 35-40.

Macknick, J., R. Newmark, G. Heath, and K.C. Hallett. 2011. "A Review of Operational Water Consumption and Withdrawal Factors for Electricity Generating Technologies." NREL/TP6A20-50900. National Renewable Energy Laboratory.

2012. "Operational Water Consumption and Withdrawal Factors for Electricity Generating Technologies: A Review of Existing Literature.” Environmental Research Letters 7.

Mahon, W.A.J., G.D. McDowell, and J.B. Finlayson. 1980. "Carbon Dioxide: Its Role in Geothermal Systems." New Zealand Journal of Science 23: 133-48.

Mansure, A. J. 2011. "Energy Returned on Investment of Engineered Geothermal Systems Annual Report Fy2011.” DOE/EE/0002740-2. A.J. Mansure.

http://www.osti.gov/scitech/biblio/1030494-energy-returned-investment-engineered-geothermalsystems-annual-report-fy2011.

Marchand, Mathilde, Isabelle Blanc, Aline Marquand, Antoine Beylot, Sophie BezelguesCourtade, and Hervé Traineau. 2015. "Life Cycle Assessment of High Temperature Geothermal Energy Systems." In World Geothermal Congress 2015, 11-Article. https://hal.archivesouvertes.fr/hal-01146355/document. 
Martin, Jennifer A. 1997. “A Total Fuel Cycle Approach to Reducing Greenhouse Gas Emissions: Solar Generation Technologies as Greenhouse Gas Offsets in U.S. Utility Systems." Solar Energy (Selected Proceeding of ISES 1995: Solar World Congress. Part IV) 59 (4-6): 195-203. doi:10.1016/S0038-092X(96)00150-8.

Martínez-Corona, Jorge Isaac, Thomas Gibon, Edgar G. Hertwich, and Roberto Parra-Saldívar. 2017. "Hybrid Life Cycle Assessment of a Geothermal Plant: From Physical to Monetary Inventory Accounting." Journal of Cleaner Production 142 (January): 2509-23. doi:10.1016/j.jclepro.2016.11.024.

Martin-Gamboa, Mario, Diego Iribarren, and Javier Dufour. 2015. "On the Environmental Suitability of High- and Low-Enthalpy Geothermal Systems." Geothermics 53 (January): 27-37. doi:10.1016/j.geothermics.2014.03.012.

Mason, I. G., S. C. Page, and A. G. Williamson. 2010. “A 100\% Renewable Electricity Generation System for New Zealand Utilising Hydro, Wind, Geothermal and Biomass Resources.” Energy Policy 38 (8): 3973-84.

Mattinen, Maija K., Ari Nissinen, Sampsa Hyysalo, and Jouni K. Juntunen. 2015. "Energy Use and Greenhouse Gas Emissions of Air-Source Heat Pump and Innovative Ground-Source Air Heat Pump in a Cold Climate." Journal of Industrial Ecology 19 (1): 61-70. doi:10.1111/jiec.12166.

Matuszewska, Dominika. 2011. "Environomic Optimal Design of Geothermal Conversion Systems Using Life Cycle Assessment.” Thesis. https://skemman.is/handle/1946/7749.

McCulloch, J., J. Gastineau, D.L. Bour, and K. Ravi. 2003. "Life Cycle Modeling of Wellbore Cement Systems Used for Enhanced Geothermal System Development." GRC Transactions 27 (2003):147-54.

McFarlane, Joanna, Kevin J. Qualls, A. L. Qualls, Adrian S. Sabau, Steven A. Wright, Hebi Yin, Lawrence \{Larry\} M. Anovitz, and Andrew K. Kercher. 2012. "Ways to Minimize Water Usage in Engineered Geothermal Systems.” ORNL/TM-2012/412. Oak Ridge National Laboratory (ORNL). http://www.osti.gov/scitech/biblio/1050888-ways-minimize-water-usage-engineeredgeothermal-systems.

Meldrum, J., S. Nettles-Anderson, G. Heath, and J. Macknick. 2013. "Life Cycle Water Use for Electricity Generation: A Review and Harmonization of Literature Estimates." Environmental Research Letters 8 (1). doi:10.1088/1748-9326/8/1/015031.

Menberg, Kathrin, Stephan Pfister, Philipp Blum, and Peter Bayer. 2016. "A Matter of Meters: State of the Art in the Life Cycle Assessment of Enhanced Geothermal Systems." Energy \& Environmental Science 9 (9): 2720-43. doi:10.1039/C6EE01043A.

Miller, Sanford A. 1996. "Incorporating Economic and Environmental Externalities of Geothermal and Natural Gas Generation Technologies." GRC Transactions 20 (1996):187-93. 
Mirasgedis, S., and D. Diakoulaki. 1997. "Multicriteria Analysis vs. Externalities Assessment for the Comparative Evaluation of Electricity Generation Systems." European Journal of Operational Research 102 (2): 364-79.

Mohan, A.R., U. Turaga, V. Subbaraman, V. Shembekar, D. Elsworth, and S.V. Pisupati. 2015. "Modeling the CO2-Based Enhanced Geothermal System (EGS) Paired with Integrated Gasification Combined Cycle (IGCC) for Symbiotic Integration of Carbon Dioxide Sequestration with Geothermal Heat Utilization." International Journal of Greenhouse Gas Control 32: 197-212. doi:10.1016/j.ijggc.2014.10.016.

Morrissey, Elmer, James O’Donnell, Marcus Keane, and Vladimir Bazjanac. 2004. "Specification and Implementation of IFC Based Performance Metrics to Support Building Life Cycle Assessment of Hybrid Energy Systems." LBNL/PUB--906. Berkeley, CA: Lawrence Berkeley National Laboratory. http://www.osti.gov/bridge/servlets/purl/841886Js5qdZ/native/841886.pdf.

Nill, M. 2004. "The future development of power generation engineering. An ecological analysis against background of technical and economical coherences; Die zukuenftige Entwicklung von Stromerzeugungstechniken. Eine oekologische Analyse vor dem Hintergrund technischer und oekonomischer Zusammenhaenge." Hamburg, Germany: Technische Univ. Hamburg-Harburg, Hamburg (Germany). ETDE.

Nitkiewicz, Anna, and Robert Sekret. 2014. "Comparison of LCA Results of Low Temperature Heat Plant Using Electric Heat Pump, Absorption Heat Pump and Gas-Fired Boiler.” Energy Conversion and Management 87 (November): 647-52. doi:10.1016/j.enconman.2014.07.032.

Onat, Nevzat, and Haydar Bayar. 2010. "The Sustainability Indicators of Power Production Systems." Renewable and Sustainable Energy Reviews 14 (9): 3108-15.

Pehnt, Martin. 2006. "Dynamic Life Cycle Assessment (LCA) of Renewable Energy Technologies.” Renewable Energy 31 (1): 55-71. doi:10.1016/j.renene.2005.03.002.

Pfister, Stephan, Dominik Saner, and Annette Koehler. 2011. "The Environmental Relevance of Freshwater Consumption in Global Power Production." The International Journal of Life Cycle Assessment 16 (6): 580-91. doi:10.1007/s11367-011-0284-8.

Rentizelas, Athanasios, and Dimitrios Georgakellos. 2014. "Incorporating Life Cycle External Cost in Optimization of the Electricity Generation Mix." Energy Policy 65 (February): 134-49. doi:10.1016/j.enpol.2013.10.023.

Rice, William L. R. 1980. “Geothermal Energy, Society and the Environment - Triad, Not Triage.” In Proceedings - Institute of Environmental Sciences, pp. 407-13.

Ristimäki, M., A. Säynäjoki, J. Heinonen, and S. Junnila. 2013. “Combining Life Cycle Costing and Life Cycle Assessment for an Analysis of a New Residential District Energy System Design.” Energy 63: 168-79. doi:10.1016/j.energy.2013.10.030. 
Rodríguez, J., I. Bangueses, and M. Castro. 2012. "Life Cycle Analysis of a Geothermal Heatpump Installation and Comparison with a Conventional Fuel Boiler System in a Nursery School in Galicia (Spain)." In 2nd European Energy Conference, Maastricht, Netherlands, April 17-21, 2012. Vol. 33. doi:10.1051/epjconf/20123305003.

Rogge, S., and M. Kaltschmitt. 2003. "Electricity and heat production from geothermal energy An ecologic comparison.” Erdoel Erdgas Kohle/EKEP 119 (1): 35-40.

Roth, I.F., and L.L. Ambs. 2004. "Incorporating Externalities into a Full Cost Approach to Electric Power Generation Life-Cycle Costing.” Energy 29 (12-15 SPEC. ISS.): 2125-44. doi:10.1016/j.energy.2004.03.016.

Rule, B.M., Z.J. Worth, and C.A. Boyle. 2009. "Comparison of Life Cycle Carbon Dioxide Emissions and Embodied Energy in Four Renewable Electricity Generation Technologies in New Zealand.” Environmental Science \& Technology 43 (16): 6406-13. doi:10.1021/es900125e.

Russo, Giovanni, Alexandros S. Anifantis, and Giacomo Scarascia Mugnozza. 2014. "Environmental Analysis of Geothermal Heat Pump and LPG Greenhouse Heating Systems." Biosystems Engineering 127 (November): 11-23. doi:10.1016/j.biosystemseng.2014.08.002.

Ruzzenenti, Franco, Mirko Bravi, Duccio Tempesti, Enrica Salvatici, Giampaolo Manfrida, and Riccardo Basosi. 2014. "Evaluation of the Environmental Sustainability of a Micro CHP System Fueled by Low-Temperature Geothermal and Solar Energy.” Energy Conversion and Management 78 (February): 611-16. doi:10.1016/j.enconman.2013.11.025.

Sabonnadiere, J.C., N. Alazard-Toux, S. His, F. Douard, J.L. Duplan, F. Monot, F. Jaudin, L. Le Bel, and P. Labeyrie. 2007. New energy technologies 3 - Geothermal and biomass energies; Nouvelles technologies de l'energie 3 - Geothermie et energies de la biomasse. Paris: Lavoisier, Paris (France).

Sakurai, K., K. Matsubara, and K. Sakuta. 2011. "Energy Payback and GHG Emissions of Renewable Power Generation Systems in Japan: A Review." In 2011 37th IEEE Photovoltaic Specialists Conference (PVSC), 003277-79. doi:10.1109/PVSC.2011.6186637.

San Martin, Robert L. 1989. "Environmental Emissions From Energy Technology Systems: The Total Fuel Cycle." US Dept of Energy. ETDE. http://www.osti.gov/bridge/servlets/purl/841886Js5qdZ/native/841886.pdf.

Saner, D., C. Vadenbo, B. Steubing, and S. Hellweg. 2014. "Regionalized LCA-Based Optimization of Building Energy Supply: Method and Case Study for a Swiss Municipality." Environmental Science and Technology 48 (13): 7651-59. doi:10.1021/es500151q.

Saner, Dominik, Ronnie Juraske, Markus Kübert, Philipp Blum, Stefanie Hellweg, and Peter Bayer. 2010. "Is It Only CO2 That Matters? A Life Cycle Perspective on Shallow Geothermal Systems." Renewable and Sustainable Energy Reviews 14 (7): 1798-1813.

Santoyo-Castelazo, E., H. Gujba, and A. Azapagic. 2011. "Life Cycle Assessment of Electricity Generation in Mexico.” Energy 36 (3): 1488-99. doi:10.1016/j.energy.2011.01.018. 
Schroeder, J.N., C.E. Clark, and C.B. Harto. 2014. "Geothermal Water Consumption and Life Cycle Water Analysis." GRC Transactions 38 (2014):871-77.

http://www.scopus.com/inward/record.url?eid=2-s2.0-

84937897862\&partnerID=40\&md5=4ffa2d4e390f9bc3da3b8173c5452dc8.

Schroeder, J.N., C.B. Harto, and C.E. Clark. 2013. "Utilizing Federal Policy Documentation to Obtain Project-Level Water Data for Geothermal Energy Facilities." GRC Transactions 37 (2013):811-16. http://www.scopus.com/inward/record.url?eid=2-s2.084897670817\&partnerID=40\&md5=50b875bd17b0c53b065725b3d00eb5a2.

Schroeder, J.N., C.B. Harto, R.M. Horner, and C.E. Clark. 2014. "Geothermal Water Use: Life Cycle Water Consumption, Water Resource Assessment, and Water Policy Framework." ANL/EVS-14/2. Environmental Science Division, Argonne National Laboratory.

Sivasakthivel, T., K. Murugesan, and P. K. Sahoo. 2015. "Study of Technical, Economical and Environmental Viability of Ground Source Heat Pump System for Himalayan Cities of India." Renewable \& Sustainable Energy Reviews 48 (August): 452-62. doi:10.1016/j.rser.2015.04.008.

Skone, Timothy J., James Littlefield, Robert Eckard, Greg Cooney, and Joe Marriott. 2012. "Role of Alternative Energy Sources: Geothermal Technology Assessment." DOE/NETL2012/1531. U.S. National Energy Technology Laboratory. http://netl.doe.gov/energyanalyses/pubs/GeothermalTARNETL.pdf.

Sovacool, B.K. 2008. "Valuing the Greenhouse Gas Emissions from Nuclear Power: A Critical Survey." Energy Policy, no. 36: 2950-63.

- 2010. "Exploring the Hypothetical Limits to a Nuclear and Renewable Electricity Future." International Journal of Energy Research 34 (13): 1183-94. doi:10.1002/er.1638.

Sullivan, J. L., C. E. Clark, L. Yuan, J. Han, and M. (Energy Systems) Wang. 2011. "Life-Cycle Analysis Results for Geothermal Systems in Comparison to Other Power Systems: Part Ii." ANL/ESD/11-12. Argonne National Laboratory (ANL).

http://www.osti.gov/scitech/biblio/1035022-life-cycle-analysis-results-geothermal-systemscomparison-other-power-systems-part-ii.

Sullivan, J. L., C. Clark, J. Han, C. Harto, and M. Wang. 2013. "Cumulative Energy, Emissions, and Water Consumption for Geothermal Electric Power Production." Journal of Renewable and Sustainable Energy 5 (2): 23127. doi:10.1063/1.4798315.

Sullivan, J. L., C. Clark, J. Han, and M. Wang. 2010. "Life-Cycle Analysis Results of Geothermal Systems in Comparison to Other Power Systems." Argonne National Laboratory.

Sullivan, J. L., E. D. Frank, J. Han, A. Elgowainy, and M. Q. (Energy Systems) Wang. 2012. "Geothermal Life Cycle Assessment - Part 3." ANL/ESD/12-15. Argonne National Laboratory (ANL). http://www.osti.gov/scitech/biblio/1118131-geothermal-life-cycle-assessment-part. 
Sullivan, J. L., T. Stephens, and M. (Energy Systems) Wang. 2014. "Geothermal Power Production: Alternative Scenarios and Critical Issues.” ANL/ESD-14/2. Argonne National Laboratory (ANL). http://www.osti.gov/scitech/biblio/1132252-geothermal-power-productionalternative-scenarios-critical-issues.

Sullivan, J. L., and M. Q. Wang. 2013a. "Life Cycle Greenhouse Gas Emissions from Geothermal Electricity Production." Journal of Renewable and Sustainable Energy 5 (6): 63122. doi:10.1063/1.4841235.

Sullivan, J. L., and M. Q. Wang. 2013b. "Impact of Well Field Exploration on the Life Cycle Analysis of Geothermal Power Production." GRC Transactions 37 (2013):817-22. http://www.scopus.com/inward/record.url?eid=2-s2.084897658061\&partnerID=40\&md5=04beaa90c9882ab8987ce4b7dfb5b006.

Tolba, M.K., and Y. ElMahgary. 1985. "The Environmental Impacts of Production and Energy Use, Part IV - The Comparative Assessment of the Environmental Impacts of Energy Sources." 85-5921. United Nations Environment Programme.

Tomasini-Montenegro, C., E. Santoyo-Castelazo, H. Gujba, R. J. Romero, and E. Santoyo. 2017. "Life Cycle Assessment of Geothermal Power Generation Technologies: An Updated Review." Applied Thermal Engineering 114 (March): 1119-36. doi:10.1016/j.applthermaleng.2016.10.074.

Treyer, K., and C. Bauer. 2010. "Life Cycle Inventories of Electricity Generation and Power Supply in Version 3 of the Ecoinvent Database - part I: Electricity Generation." International Journal of Life Cycle Assessment, 1-19.

Treyer, Karin, Christian Bauer, and Andrew Simons. 2014. "Human Health Impacts in the Life Cycle of Future European Electricity Generation." Energy Policy 74, Supplement 1 (December): S31-44. doi:10.1016/j.enpol.2014.03.034.

Twidell, J.W., and Weir, A.D. 1986. Renewable Energy Resources. New York, NY: E\& F N Spon Ltd.

Uchiyama, Y. 1994. "Life cycle assessment (LCA) as an energy system. Energy balance at electric power plants and their effects on global warming; Energy system to LCA hyoka. Hatsuden plant no energy shushi to ondanka eikyo." Nippon No Kagaku To Gijutsu (Japan Science and Technology) 35 (273): 44-49.

— 1996a. "Validity of Fench GHG Study: Methodologies and Databases." IAEA advisory group meeting on analysis of net energy balance and full-energy-chain greenhouse gas emissions for nuclear and other energy systems, October 4-7, 1994. Beijing, China. International Atomic Energy Agency. pp. 85-94. 
1996b. "Life Cycle Analysis of Electricity Generation and Supply Systems: Net Energy Analysis and Greenhouse Gas Emissions." Proceedings Electricity, Health and the Environment: Comparative Assessment in Support of Decision Making, Vienna, Austria, October 16-19, 1995. pp. 279-91.

http://www.iaea.org/inis/collection/NCLCollectionStore/_Public/28/006/28006115.pdf\#page=29 3.

1997. "Environmental life cycle analysis of geothermal power generating technology; Chinetsu hatsuden gijutsu no kankyo life cycle bunseki." Denki Gakkaishi (Journal of the Institute of Electrical Engineers in Japan) 117 (11): 752-55.

—. 2007. "Life Cycle Assessment of Renewable Energy Generation Technologies." IEEJ Transactions on Electrical and Electronic Engineering 2 (1): 44-48.

van de Vate, J.F. 1994. "Full Energy Chain Analysis of Greenhouse Gas Emissions from Different Energy Sources." IAEA Advisory Group meeting/Workshop, International Atomic Energy Agency, Beijing, China, October 4-7, 1994. pp. 11-17.

Vasquez, V.R., and O. Hanbury. 2011. "Life Cycle Analysis of Geothermal Energy Extraction." In Proceedings of AIChE Annual Meeting, Minneapolis, Minnesota, October 16-21, 2011. http://www.scopus.com/inward/record.url?eid=2-s2.084857214965\&partnerID=40\&md5=8e706934038f33c433f1 17010ddda4f2.

Widiyanto, A., S. Kato, and N. Maruyama. 2002. "A LCA/LCC Optimized Selection of Power Plant System with Additional Facilities Options." Journal of Energy Resources TechnologyTransactions of the ASME 124 (4): 290-99. doi:10.1115/1.1507329.

Wong, K.V., and N. Tan. 2014. "Feasibility of Using More Geothermal Energy to Generate Electricity." Journal of Energy Resources Technology, Transactions of the ASME 137 (4). doi:10.1115/1.4028138. 